\title{
School and family effects on educational outcomes across countries
}

\section{Citation}

Freeman, Richard B., and Martina Viarengo. 2014. "School and Family Effects on Educational Outcomes Across Countries." Econ Policy 29 (79) (July): 395-446. doi:10.1111/1468-0327.12033.

\section{Published Version}

doi:10.1111/1468-0327.12033

\section{Permanent link}

http://nrs.harvard.edu/urn-3:HUL.InstRepos:25811018

\section{Terms of Use}

This article was downloaded from Harvard University's DASH repository, and is made available under the terms and conditions applicable to Open Access Policy Articles, as set forth at http:// nrs.harvard.edu/urn-3:HUL.InstRepos:dash.current.terms-of-use\#OAP

\section{Share Your Story}

The Harvard community has made this article openly available.

Please share how this access benefits you. Submit a story.

\section{Accessibility}




\title{
School and Family Effects on Educational Outcomes across Countries'
}

\author{
Richard B. Freeman* and Martina Viarengo** \\ *Harvard University and NBER; **The Graduate Institute, Geneva and Harvard's Center for \\ International Development
}

\begin{abstract}
This study analyzes the link between student test scores and the school students attend, the policies and practices of the schools, students' family background and their parents' involvement in their education using data from the 2009 wave of the Program for International Student Assessment. We find that 1) a substantial proportion of the variation of test scores within countries is associated with the school students attend; 2) a sizable proportion of the school fixed effects is associated with school policies and teaching practices beyond national policies or other mechanisms that sort students of differing abilities among schools; 3) school fixed effects are a major pathway for the link between family background and test scores. The implication is that what schools do is important in the level and dispersion of test scores, suggesting the value of further analysis of what goes in schools to pin down causal links between policies and practices and test score outcomes.
\end{abstract}

Herbert Ascherman Chair in Economics at Harvard University and Director of the National Bureau of Economic Research / Sloan Science Engineering Workforce Projects; Assistant Professor of Economics at the Graduate Institute, Geneva and Faculty Associate at the Harvard's Center for International Development. Corresponding author is Martina Viarengo (martina.viarengo@graduateinstitute.ch). This is a revised version of a paper prepared for the 58 ${ }^{\text {th }}$ Panel Meeting of Economic Policy, hosted by the Bank of Lithuania. We are grateful to the Editors, Members of the Economic Policy Panel, the two Discussants: Daniele Checchi and Marco Manacorda, and three anonymous Referees for helpful comments and suggestions. We also thank Ludger Woessmann for sharing with us his dataset on school tracking. Viarengo gratefully acknowledges support received from the British Academy and the Royal Society. The Editor in charge of this paper was Tullio Jappelli. 


\section{Introduction}

This study uses the Organisation for Economic Cooperation and Development's (OECD) Program for International Student Assessment data set (PISA) to assess the link between student test scores and the school students attend, school policies and practices, students' family background and parental involvement in education. PISA provides data on test scores, schools, and family background for hundreds of thousands of students around the world, which makes it the largest cross-country data set in the world for analyzing the relation between test scores and their potential determinants. Our focus on schools and school level policies/practices and parental involvement in education provides a more granular picture of the factors associated with student achievement than is found in studies focused on country-level policies such as national standards and external exit examinations. ${ }^{2}$

We find that school "fixed effects" are the most important factor associated with student test scores within countries and a major mediator of the relation between family background and scores. To paraphrase the famous campaign slogan of President Clinton, the data tell us "it's the schools, stupid". ${ }^{3}$ We identify school level teaching practices as reported by students as major correlates of the relation between the schools students attend and test scores, which makes them a potential target for policies to improve outcomes.

There are two pathways by which test score outcomes will vary with the school students attend. The first pathway is through sorting of students of similar ability into the same schools due to national policies on tracking, admissions policies of schools or parent/student or teacher behavior. Sorting creates differences in outcomes among schools without necessarily affecting the performance of students. The second pathway is through school level educational policies/practices that affect student achievement, with "good schools" raising the test scores of students more than "poor schools".

Differentiating between sorting and educational effects is difficult in international test data. To get some notion of the effect of tracking, we contrast the magnitude of school effects in countries that assign students at early ages to schools beyond their first school to the magnitude of school effects in countries that assign them later. We find evidence of a sorting effect: school fixed effects are larger in countries that assign students to schools earlier than in other schools. But we also find that school effects are large in the countries without such tracking practices, which suggests that the school effect on test performance goes beyond national sorting policies and involves some actual difference in educational

2 Woessmann (2003a), Schuetz et al. (2008), find that standards and exit exams affect national test scores. Studies using other data also show that standards and exit examinations are associated with better student performance (Bishop 1997, 2006; Woessmann 2003b for the TIMSS 1995; Woessmann 2005a; Jurges et al. 2005; Greene and Winters 2005). Studies also find that having an effective link between assessment and curriculum (Bishop 2006) and keeping high standards (Peterson and Hess 2006, 2008) improve outcomes, and that increased school autonomy positively affects student performance when combined with an accountability system and external exams (Woessmann 2005a). An increasing number of countries and states in the US require following a specified curriculum and passing an exit examination for high school graduation. (Ou 2010; Peterson and Hess 2008).

http://en.wikipedia.org/wiki/It's_the_economy,_stupid. 
policies/practices among schools. We identify some of the relevant policies and practices in the PISA data on the basis of the responses of principals and students to questions about how the school operated.

In the PISA data set, as in virtually all other test score data, students from more advantaged backgrounds perform better on tests than other students. We find that addition of school dummy variables to test score equations substantially reduces the estimated impact of family background on scores. The effects are large in countries with tracking policies and in countries without tracking policies, suggesting that schools are major pathway by which parental background relates to student test scores irrespective of the way students are sorted among schools. PISA measures of parental involvement in student education, by contrast, do not account for much of the family background effect on test scores.

The body of the paper consists of five sections. Section two reviews the education studies on which our analysis builds. Section three describes the PISA data, the equation we use to relate test scores to school and family background variables, and the way we draw inferences about school effects from the data. ${ }^{4}$ Section four presents the estimates of school fixed effects and the impact of school policies and practices on those effects. Section five gives our analysis of the role of schools and specific parenting practices as mediators for the link between family background and test scores. Section six draws implications for policy.

\section{Previous Research}

This section reviews studies on "tracking and other sorting mechanisms", "school policies and practices", and "family background and parental involvement" that provide the background research on which we build our analysis.

\section{A) Tracking and other Sorting Mechanisms}

Researchers in education have long recognized the potential importance of tracking, defined as the explicit streaming of students into different types of schools according to their academic performance, on educational outcomes and the transmission of parental socioeconomic position to their children (Betts 2011). Studies of the effects of sorting on test scores across countries indicate that early tracking increases inequality in educational outcomes without improving national scores (Hanushek and Woessmann 2006); adds to the impact of family background on educational achievement (Schuetz et al. 2008; Woessmann et al. 2009) and labor market earnings (Brunello and Checchi 2007). But national tracking policies are not the only source of sorting students among schools. Parents/students can selfsort into particular schools, from private schools to public schools of differing quality;

4 Woessmann (2005b) compared the importance of family background of five Asian countries (Hong Kong, Japan, Singapore, Korea and Thailand) to three Western countries (France, Spain and the U.S.) in the TIMSS 1995 study. 
teachers of different qualities can be recruited and choose to work in particular schools; and the government or private groups can allocate other educational resources differentially among schools.

With respect to student self-sorting, Nechyba (2011) summarizes the following mechanisms: parental background leading to residential segregation, parental choices of private as opposed to public schools and of schools of different quality in the sectors. Nechyba notes that "while sorting mechanisms may differ across countries, there is little reason to doubt that sorting itself is a critical component of most primary and secondary school systems" (p.1029).

To the extent that residential areas correlate with the quality of schools the area in which a family lives, which will depend on family income and the housing market, can create substantial sorting (Bjorklund and Salvanes 2011). Housing markets also play a similar role in case where admission does not depend on the residential area but transportation is costly (Nechyba 2011). Another family-based mechanism for sorting is through parental education. More educated parents presumably have better information on the different quality of schools (Bjorklund and Salvanes (2011, p.215)), and will push harder for getting their children into the better schools compared to less educated parents. Sorting related to education may be closely related to sorting through economic resources but may also be independent of income as suggested by Bjorklund and Salvanes (2011). And the ability or other characteristics of students will likely play some role in these modes of sorting.

Finally, there is the sorting between public and private schools, which researchers have explored both with observational and experimental methods (Epple and Romano 1998; Angrist et al. 2002; Altonji et al. 2005). This source of sorting may be related to family background and income, student ability or other characteristics. To the extent that the private school sector is well-funded, it may work as a sorting mechanism even for young persons of modest means, by giving scholarships to the more able, and even for young persons of modest academic ability, by giving scholarships for athletic or other talent.

Students aside, the decisions of schools to offer teaching jobs to teachers of differing characteristics and teachers' acceptance or rejection of job offers can create sorting of teachers across schools that will impact student performance. Hanushek and Rivkin (2006)'s review of studies on teacher labor markets acknowledges the importance of measuring teacher quality and the difficulty related to selection and unobserved characteristics: "Credible research into training versus selection issues as related to certification policies, merit pay, and so forth clearly requires longitudinal observations that link teachers, programs, and student performance. Until recently, there has been little possibility of such work" (p.1073). A similar problem is found in the estimation of teachers earnings equations (Dolton 2006). Still, using a data-rich data set on teachers in New York Lankford et al. (2002) found that disadvantaged students are disproportionately in 
classrooms with less skilled teachers, especially in urban areas. They relate this to district differences in preferences for teaching qualifications and hiring efficiency (which will depend on the school budget), on the demand side, and teacher preferences on the supply side. They note, however, that "we know very little about sorting or the causal relationships that lead to sorting" in these situations (Lankford et al. 2002, p.39).

With respect to the allocation of other resources, schools with high performing students may obtain more and better resources while gifted students may benefit from special programs within a school or admission to schools with special resources - for instance a special math or science academy or school for music and performing arts. But the allocation of resources may be of a compensatory nature (e.g. Holmlund, McNally and Viarengo 2010; West and Woessmann 2006), In this case, more resources are allocated to more disadvantaged and low-performing students.

\section{B) School Policies and Practices}

The educational literature on the relation of school policies and practices to student performance provides a benchmark for our findings.

Studies of school selectivity invariably find that more selective schools have higher performing students than less selective schools and lower variation in scores among students (Sprietsma 2008; Jackson 2010; Pop-Eleches and Urquiola 2013). Studies of whether sorting students by classrooms within the same school benefits students by providing more targeted instruction by ability or harms students by reducing the interaction between low performing and high-performing students give inconclusive results (Betts and Shkolnik 2000; Figlio and Page 2002).

Studies of School Autonomy and Accountability ${ }^{5}$ suggest that the alignment of autonomy and accountability leads to higher outcomes (Fuchs and Woessmann 2007, Woessmann et al. 2009) but have an unclear impact on inequality of outcomes among students (Hanushek and Raymond 2003). Hanushek et al. (2013) shows that for 42 countries that participated in PISA from 2000 to 2009, school autonomy in academic content, hiring, salaries is associated with higher student learning outcomes in developed countries.

Studies of Resource inputs such as spending per student, teacher-student ratio, class size, instructional time have produced controversy. Reviewing extant studies through the early 2000s, Hanushek (2006) concludes that in advanced countries there is no compelling evidence that changes in the level of any of these resources, within the observable range of variation, have a substantive effect on educational outcomes. The Tennessee STAR study, however, gives a different picture - with a one-third reduction in class size associated with

5

Research in this area using the international studies has examined various dimensions of school autonomy (e.g., autonomy over resources allocation, hiring and firing decisions), regulations of school governance and standardized exams (e.g., periodic measurement of teacher and principal performance, standardized exams). 
higher student achievement by the equivalent of 3 additional months of schooling (Krueger 1999). But other experiments find smaller or no impacts of class size (Chingos and Whitehurst (2011); Altinok and Kingdon (2012) and Woessmann (2010)). Studies relating to teachers' characteristics such experience, academic and professional qualifications, find that while teachers matter in the sense that individual teacher fixed effects are important in explaining student test scores, observed characteristics are generally unrelated to teachers' performance (Hanushek and Rivkin (2006)).

With respect to school Practices, Bratti et al. (2011) find that cooperative behavior among students through group learning improves educational outcomes. By relying on a quasi-experimental approach for students in primary and middle schools in Israel, Lavy (2011) finds a positive impact on learning outcomes associated with teaching practices which include group learning activities and activities that focus on developing students' analytical and critical skills. Examining learning practices in several waves of TIMSS, and PIRLS, Algan, Cahuc and Shleifer (2013) find that "horizontal teaching practices" (i.e., students work in groups, ask questions) is related to pro-social beliefs while "vertical teaching practices" have the opposite effect. Comparing student reports of teaching practices Bietenbeck (2011) reports that memorization and lecture-style teaching produce better outcomes whereas selected teaching practices such as working in groups, students' autonomy in problem-solving decisions have a small insignificant effect on learning outcomes. Schwerdt and Wuppermann (2011) compare lecture-style teaching to problem solving and find a positive association between the practice of lecture-style teaching and students' test scores.

\section{C) Family Background and Parental Involvement}

Studies of the educational achievement of young persons invariably find that children from more advantaged backgrounds perform better on average in school in terms of test scores and other school outcomes, albeit with heterogeneity in the magnitude of the impact of background factors among countries (Freeman, Machin and Viarengo 2011; Hanushek and Woessmann (2011a)) and with differences related to the measure of background. Ammermuller et al. (2005) and Woessmann (2005b, 2008) use parental education to analyze background effects on children's education. Other researchers favor the books at home measure as reflecting not only the parents' scholarly culture but also the socio-economic background of the household (Di Maggio 1982, Dronkers 1992). Ammermuller et al. (2005), Woessmann (2003a, 2005b, 2008), Schuetz et al. (2008) use books at home in analyses of educational outcomes in different waves of TIMSS while Peterson and Woessmann (2007) analyze it in the PISA 2003. Other scholars have relied on the socioeconomic and cultural status index. Jenkins et al. (2008) and Machin and McNally (2012) 
among others report significant relation between this index and learning outcomes.

Research on parental participation in home and school-related activities finds a positive association between parental involvement and students' learning outcomes (Bordieu 1986, Coleman 1988, Hoover-Dempsey and Sandler 1997). But Desforges and Abouchaar's (2003) note the limitation of evaluations which do not satisfactorily address the endogeneity of parental involvement. Parents with greater education and resources are likely to invest more time and resources in their children's education than less educated parents or those with fewer resources. Parents are also more likely to invest in the education of children who are more receptive and/or in children having problems in school - for instance meeting with teachers or providing help with homework. Country-specific longitudinal studies (e.g., the UK National Child Development Study, the British Cohort Study, US National Educational Longitudinal Study) suggest that parental participation in learning activities at home (Schoon and Parsons 2002), aspirations for children's continuing in education (Singh et al. 1995), discussion of school experience and involvement in cultural and learning activities (George and Kaplan 1998) are positively associated with children's educational performance conditional on the socio-economic status of parents.

\section{PISA Dataset and Empirical Analysis}

\section{A) Data}

Beginning in 2000 the PISA study has tested 15 year-old students on their skills, knowledge, and ability to use this knowledge to solve problems in real-life situations every three years. ${ }^{6}$ The tests cover mathematics, science, and reading. Participating countries randomly select schools to administer the test and randomly select students within the schools to provide a nationally representative sample of students. PISA standardizes test scores to a mean of 500 and standard deviation of 100 on the basis of the 2003 PISA. Differences in test scores can thus be interpreted in terms of percentage points of an international standard deviation. An increasing number of countries have participated in each succeeding wave, including developing countries outside the OECD.

We use data on students and schools from the 2009 wave. This data set provides information on about 520,000 students in 18,641 schools from 74 economies $^{7}$, of whom 34

6 Students' age varies between 15 years 3 months and 16 years 2 months and to be eligible to participate must have completed at least six years of formal schooling (OECD 2010a).

7 Around 470,000 students in 65 countries participated to PISA 2009. In addition to this, about 50,000 students were tested in 2010 in the framework of PISA 2009+ (from 7 countries and 2 Indian states (Himachal Pradesh and Tamil Nadu).This was the same assessment as PISA 2009 but carried out one year later. More information on PISA 2009 and PISA 2009+ is available at https:/mypisa.acer.edu.au/. This is list of countries and economies: Albania, Argentina, Australia, Austria, Azerbaijan, Belgium, Brazil, Bulgaria, Canada, Chile, Chinese Taipei, Colombia, Costa Rica, Croatia, Czech Republic, Denmark, Estonia, Finland, France, Georgia, Germany, Great Britain, Greece, Himal Pradesh - India, Hong Kong, Hungary, Iceland, Indonesia, Ireland, Israel, Italy, Japan, Jordan, Kazakhstan, Korea, Kyrgyzstan, Latvia, Liechtenstein, Lithuania, Luxembourg, Macao-China, Malaysia, Malta, 
are OECD countries and 31 are "partner countries" outside the OECD. In addition to the PISA tests, students fill a questionnaire on their characteristics, family structure, and background; while principals of each participating school report on school characteristics, policies, and practices. In addition, fourteen countries administered a questionnaire to parents regarding their involvement at home with the child and in school-related activities, ${ }^{8}$ including involvement when children were in primary schooling (ISCED 1). ${ }^{9}$

We analyzed test outcomes in mathematics, reading, science, and some non-cognitive measures of performance. ${ }^{10}$ The results for the different test scores are sufficiently similar that we report in this paper only those for mathematics. Results for the other tests are available on request from the corresponding author.

We analyze students in the full set of countries in the PISA and then group the countries into five subsets: OECD economies, European Union economies, Asian economies, other high income economies, and middle income economies. ${ }^{11}$ Countries can appear in more than one subset in our groups: for instance the EU countries are also part of the OECD country subset. We differentiate the Asian countries because five of the top ten scoring countries in PISA 2009 were Asian, which raises questions about how they differ from other countries in educational practices. ${ }^{12}$

\section{B) Empirical Framework}

At the heart of our analysis are estimates of variants of the following equation:

$\mathrm{T}_{i s c}=\alpha_{1} \mathrm{~F}_{i s c}+\alpha_{2} \mathrm{FP}_{i s c}+\beta_{1} \mathrm{X}_{i s c}+\beta_{2} \mathrm{~S}_{s c}+\beta_{3} \mathrm{SD}_{s c}+\mu_{c}+\varepsilon_{i s c}$

Mauritius, Mexico, Miranda-Venezuela, Moldova, Montenegro, Netherlands, New Zealand, Norway, Panama, Peru, Poland, Portugal, Qatar, Romania, Russian Federation, Serbia, Shanghai-China, Singapore, Slovak Republic, Slovenia, Spain, Sweden, Switzerland, Tamil Nadu - India, Thailand, Trinidad and Tobago, Tunisia, Turkey, United Arab Emirates, United States, Uruguay.

The data set is publicly available from the PISA website: http://pisa2009.acer.edu.au/.

Throughout, we use the sampling weights in the database as described in PISA Technical Report 2009 (OECD 2012a). To deal with missing observations, we kept all students with complete test score data and imputed the values of missing explanatory variables by 10 using mean values and including in the regression an indicator for missing data. (See Hanushek et al. 2013).

Our analysis of non-cognitive learning outcomes considered indicators related to disruptive behavior and two psychological traits central to the five factors model (Costa and McCrae 1992; Peterson and Viarengo 2011): openness to learning (attitude towards school) and locus of control (self-confidence in ICT high-level tasks). Non-cognitive skills have been largely neglected in the crosscountry studies due to the paucity of information available and difficulties of measurement (Woessmann et al. 2007; Brunello and Schlotter 2011)

Footnote 7 provides the list of countries in our analysis. Korea and Japan are Asian countries members of the OECD. Mexico is a middle-income country member of the OECD. For the purpose of the analysis that follows Korea and Japan are included in the Asian group and Mexico in the middle-income group.

12

The Asian countries have large shares of students at the proficient level 5 (OECD 2010b). PISA classifies students into five proficiency levels, "moderate" performers achieve proficiency levels of 2 or 3 whereas "top" performers achieve proficiency levels of 5 or 6. OECD (2010a, p.8; Peterson et al. 2011, p.8). More than 20 percent students in Korea, Japan and Hong Kong perform above proficiency level 5 (OECD 2010c, p.63)) and above the advanced international benchmark of 625 or better. Cross-national surveys of learning achievement show that Korea, Macao, Shanghai combine top scores with levels of inequality below the OECD average (e.g., (OECD 2010b, p.53)) 
Where:

$\mathrm{T}$ is the test score of student $i$ in school $s$ of country $c$, $\mathrm{F}$ is a measure of family background characteristics for student $i$ in school $s$ of country $c$, $\mathrm{FP}$ is a measure of the parenting practices for student $i$ in school $s$ of country $c$, $\mathrm{X}$ is a vector of the student's characteristics, for student $i$ in school $s$ of country $c$, $\mathrm{S}$ is a vector of the policies and practices of school $s$ of country $c$. $\mathrm{SD}$ is a vector of dummy variables for each school in the data $\mathrm{set}^{13}$ $\mu_{c}$ is a vector of country dummy variables $\varepsilon$ is an error term ${ }^{14}$ $\alpha_{1}, \alpha_{2}, \beta_{1}, \beta_{2,} \beta_{3}$ are vectors of coefficients to be estimated.

Because PISA gathers data on test scores from about 35 students in each school, we have two ways to examine the relation between the schools students attend and test scores. The first way is a "sibling" type estimate based on estimating the school level dummies SD. To obtain the fixed school effect we omit the policy and practice vector in equation (1) (that is, we set $\beta_{2}$ at 0 ). Just as sibling studies of family background effects use the fact that siblings grow up in the same family to estimate the variance in outcomes associated with family background without measuring that background, ${ }^{15}$ the PISA data allow us to estimate school effects through the similarity of outcomes among students in the same school absent measures of school policies and practices. The second way to examine the effects of schools on outcomes is to estimate the coefficients in the $\mathrm{S}$ vector of policies and practices in equation (1). To do this we omit the school dummy variables (that is, set $\beta_{3}$ at 0 ). The variance in test scores due to measured policies/practices will invariably fall short of the variance in test scores in school fixed effects, since the measured variables do not account for all of the differences among schools.

If students were randomly assigned to schools, the difference between the contribution to the variance of the estimated school fixed effect and the contribution to the variance in scores associated with observable school practices and policies would reflect the effect of schooling on outcomes through mechanisms rather than observable policies and practices that affect student education. But, as noted in our discussion of tracking, the assignment of students among schools is not random. Students of similar ability are likely to be sorted among schools, producing school fixed effects independent of what schools actually do for students. $^{16}$

13

In the estimation of the school fixed effect models country fixed effects are absorbed by school fixed effects.

Clustering-robust linear regression (CRLR) has been used in the estimation to estimate standard errors given the fact that the error term has both a school-level and a student-level components.

Bjorklund and Salvanes (2010) report that factors shared by siblings explain more than 50 percent of the overall variation in years of schooling for children in a sample of developed countries.

If different schools had no discernible effect on student performance, parental efforts to get their students into better schools would make little sense in terms of their education, so sorting practices by parents are presumably indicative of actual educational effects. 
To help differentiate the variance in test scores among schools due to sorting from the variance to what schools do to students, we first examine the effect of different measures of sorting on variances and then examine the effect of explicit policies on the variance of schools under different sorting regimes.

Approaching the problem from the sorting perspective, we contrast differences in the school fixed effects on test outcomes between countries with early sorting policies and countries with late sorting policies. We expect greater variation in the average scores among schools in countries with early tracking policies than among schools in countries without those policies. Following a similar logic, we also contrast variance in test scores among schools with different admission policies and openness to residential and parental choice to see whether those measures of sorting account for the bulk of school fixed effects.

Approaching the problem from the perspective of how schools affect student performance, we consider the contribution of school fixed effects and measures of explicit policies on test scores in countries/schools with different sorting policies. Large school fixed effects in countries or among schools without tracking policies would indicate that something other than tracking underlies school differences. But even more telling would be evidence that explicit policies and practices affect outcomes similarly among countries with and without tracking. It is difficult to argue that tracking is the whole story for school fixed effects if the evidence shows sizable effects absent tracking and relations between test scores and school policies or practices under different sorting regimes.

\section{Schools Effects: Sorting vs School Policies and Practices}

\section{A) The Role of Schools}

Table 1 records statistical properties of the math test score on which we focus. Column 1 records the mean and standard deviation (in brackets below the mean) of the test score in all the countries in the data set and in countries in the five country groupings. The mean scores for the poorest countries in our sample, "middle income countries" by the World Bank definition, fall below those of the other and higher income countries. The mean scores for the Asian countries are higher than the scores for other countries. The coefficient of variation of the test scores in column 2 shows modestly higher variation in scores among the middle income countries than others and modestly lower variation in test scores for the Asian countries than for the others. Variation of scores is, however, large among all groups, which reflects the wide distribution of scores among students within countries.

The columns under the heading "Percentage of Variance in Scores" record the proportion of the variance in test scores associated with country; measures of background;

Demonstrably better school effects on students should induce parents to make greater efforts to get able students into higher quality schools. We do not explore this interaction in this paper. 
and schools ${ }^{17}$. The proportions of variance are calculated separately for each of these factors. The column labeled country shows the percentage of variance from regressions of student test scores on country dummies. The column labeled background shows the percentage of variance from regressions of test scores on the family background measures listed in the table note. The column labeled schools shows the percentage of variance from regressions of test scores on school dummies.

Country contributes substantially to the variance in the whole data set because of the middle income countries have much lower test scores than the other countries. But within each of the groups country is associated with only a small proportion of the variance in scores. Background factors have a substantial impact on the variance in the overall sample and within every category but contribute least to the variance among the Asian countries. The largest source of variation in test scores in Table 1, however, is the school the student attends. ${ }^{18}$ The regression of test scores on the school dummies explains a large proportion of the variation of scores in all groups. Estimates of the contribution of schooling to the variance of test scores separately by country confirm this result for all countries, albeit with variation in the magnitudes. ${ }^{19}$ That the students' school is the biggest measurable contributor to the variance of test scores motivates ensuing analysis.

The first question we ask about this empirical result is the extent to which school fixed effects result from national tracking policies or other sorting practices as opposed to the potential impacts of schools on learning by students. If the variance in test scores among schools were due largely to sorting of students by prior ability/knowledge, the school effects would arguably be more indicative of efforts to preserve existing social connections and thus provide little insight into educational policy. If, by contrast, a sizable part of the school fixed effects is due to school policies and practices, the finding directs attention at the impacts of measured policies and practices and ways to transfer best practices to more schools, and to further investigation of policies and practices that the PISA does not measure.

As a first step toward measuring the extent of sorting vs educational policies/practices on the school fixed effects result we built on the research referenced in section 2 to estimate the effect of national policies toward tracking of students into higher level schools on the variance of test scores. We gathered data on the first age at which students move from one level of schooling to the next level in different countries. ${ }^{20}$ selection that affects the student composition into the different schools. In the analysis presented in the following sections of the paper different possible explanations are going to be investigated.

First age at which selection takes place in the education system (OECD 2005, Education at a Glance, Table D6.1; Hanushek and Woessmann 2006; Brunello and Checchi 2007, Woessmann 2005b; in addition to this, Prof. Ludger Woessmann kindly shared with us his international dataset on tracking acquired through detailed personal inquiries). This information refers to the policy set at the national level. 
Researchers who study national tracking systems use these data to divide countries into two groups: countries which sort students at ages less than 16 are viewed as having tracking systems while countries with a first age of sorting above age 16 are viewed as not having a tracking system. ${ }^{21}$ Given that the students in the PISA are 15-16 years old, this definition works well with our data. But rather than settling for a dichotomous division, we created a more refined measure of tracking by differentiating countries by the first age of movement to a different school. If tracking policies sort students by abilities and these measures reflect those policies, we expect that the variance of test scores among schools will be higher in countries that tracked students early in their lives than in countries that tracked them later in their lives. By contrast, the within-school variance of test scores should be lower in the tracking countries than in the non-tracking countries.

Accordingly we examined differences in the relation between test scores and schools at the level of countries and at schools within countries. At the country level, we calculated the coefficients on the vector of school dummies from equation (1), absent measures of school practices and policies. The estimated coefficients measure the fixed effects impact of each school. This is equivalent to taking the average performance of a school adjusted for the effects of student background factors. Then we related the estimated school effects to the rank of the school in the country's distribution of school scores from highest to lowest. The basic notion is that tracking should produce a steeper relation between the ranking of schools in the country's distribution of schools by test scores and the estimated school effects.

The regression of the estimated school fixed effects on the rank of the school for each country yields a coefficient $\alpha_{1}$ for country $i$ that shows how much being higher in the distribution of schools affects the test score: ${ }^{22}$

$$
\beta_{3 \mathrm{sc}}^{\prime}=\alpha_{1} R_{\mathrm{sc}}+\varepsilon_{\mathrm{sc}}
$$

Where $\beta_{3 s c}$ is the vector of estimated fixed school effects for school S in country C (i.e., the mean test score in the school adjusted for the other variables in regression (1)) and $\mathrm{R}_{\mathrm{sc}}$ is the rank of school in the distribution of test scores for the schools in country $\mathrm{C}$.

Because the PISA sample includes several countries with huge numbers of schools - Mexico (1,535 schools), Italy (1,097 schools), Brazil (947 schools) and Canada (978 schools) - the

Summarizing the relation between test score and school ranking with a single regression parameter in this manner forces a simple linear relation onto the rank-score curve. The actual curves show more complex logistic patterns, which depend on the nature of sorting, groups sorted, the number of students in schools and the bounds on school scores (which lie between the lowest and highest PISA scores multiplied by the number of students in bottom and top schools). But for the purposes of examining whether or not formal tracking systems steepen the rank score relation, the linear analysis suffices. 
range of ranks for those countries diverges hugely from the range of ranks for the typical PISA country that has on the order of 100-200 schools. The result is that estimates of equation 2 for the countries with huge numbers of schools give much smaller estimated $\alpha_{1}$ coefficients than for the other countries. To deal with this scaling issue and standardize the data for cross-country analysis, we created a new data set consisting of the estimated fixed effect for each decile of schools for each country. ${ }^{23}$ This gives us 10 average test scores for each decile and the ranks from 1 to 10 for the deciles for each country. We then regressed the score of the $1^{\text {st }}$ decile, $2^{\text {nd }}$ decile, $\ldots, 10^{\text {th }}$ decile school on the ranks of their corresponding decile. This gives us a slope coefficient for each country estimated on a similar number of observations and with a similar range of the right-hand side rank variable.

Figure 1 graphs the scores of schools against the ranks of schools in the curves for the five countries with the largest gradients and the five countries with the smallest gradients based on the decile regressions. ${ }^{24}$ By construction the curve rises monotonically, but the gradients of the rank-score curve vary substantially among countries. Countries with the largest gradient have an early tracking system whereas countries with the lowest gradient have late tracking systems, Portugal being a noticeable exception. ${ }^{25}$ The estimated slopes for countries are available from the authors and show high gradients for countries of Continental Europe (France, Germany, Hungary, the Netherlands), heterogeneous gradients for Asian countries and smaller gradients for Anglo-Saxon (Australia, Canada, Ireland) and Nordic European countries (Denmark, Finland, Norway).

To check the robustness of the country ordering by the gradient of the rank-score figure, we estimated rank-score curves for countries in three other data sets in periods close to the PISA 2009: TIMSS $20114^{\text {th }}$ grade mathematics students (41 countries overlap), TIMSS 2011 8th mathematics grade students (30 countries overlap), and PIRLS 2011, $4^{\text {th }}$ grade reading (19 countries overlap) ${ }^{26}$ Differences among the studies in design and structure as well as grade groups, notwithstanding the ordering of countries by the estimated rankscore gradient is consistent with that in PISA, with the greatest similarity between PISA and the TIMSS $4^{\text {th }}$ grade, TIMSS $8^{\text {th }}$ grade test and the least with the PIRLS $4^{\text {th }}$ grade test.

By the logic of tracking policies, countries that track students earlier should have steeper gradients linking school fixed effects to the rank of schools in the distribution of

23

24

The estimated coefficient on school rank for each country in our sample is available from the authors. The coefficients have been extracted from the country-specific regressions run at school-level. The graph for the remaining countries and territories in our 25

26

TIMSS refers to the Trends in International Mathematics and Science Study whereas PIRLS refers to the Progress in International Reading Literacy Study. Both studies are administered by the International Study Center, Lynch School of Education, Boston College, and the International Association for the Evaluation of Educational Achievement. More information is available at http://timss.bc.edu/. 
scores than countries. Similarly, the proportion of the variance of student test scores due to school effects as opposed to within school variance should be higher in countries which do more tracking.

The regressions in Panel A in Table 2 test this expectation with two measures of country tracking policies. The first measure is the standard measure of tracking systems in the cross-country literature: a dummy variable for whether the first age at which students move school levels is below 16. The second measure is the "tracking index" based on the age that countries begin tracking is available from the authors. The ages vary from 10 to 18 , but our index reverse codes them to be consistent with the dummy variable measure so that higher numbers reflect stronger tracking (i.e., the index is 18 for schools that send students to another school level at age 10,17 for those that do so at age 11, and so on). Section A2 in the appendix provides a description of these tracking variables used for the analysis.

The first two columns of Panel A of Table 2 give the results of regressing the estimated gradients of school test scores on school rank on the specified measures of tracking. The first regression excludes covariates for student characteristics. The second regression includes country averages of the covariates listed in the table note. ${ }^{27}$ The positive coefficients on the tracking dummy variable and on the tracking index show that earlier sorting of students into another level of schooling is associated with a larger gradient of test scores on school rank. A high ranking school has a higher test score compared to others in the same country when the country tracks earlier relative to a high ranking school in a country which tracks students later.

The next two columns give the results of regressing the ratio of the variance in test scores attributed to the school dummies over total variance in each country on the two measures of tracking policies with and without covariates for country characteristics of students. These regressions show that the proportion of variance between schools is larger among countries with lower ages of sorting.

Panel B of the table shifts from country level regressions to school level regressions to assess the effects of tracking policies on test scores. Here, we regress the estimated school fixed effects on the rank of each school in their own country and on country dummy variables separately for countries with early tracking policies and for countries with later tracking policies. This specification forces a single coefficient on school rank for all of the countries in each of the groups. To deal with the different number of schools in this analysis, we have weighted the observations by $1 /$ number of schools in a country. The results confirm the regression findings in the country data. The slope of the test score on the rank of schools is higher in countries with an early tracking policy than in countries without such a policy when the tracking measure is the sole explanatory variable and when we include the covariates listed in the table note. We also regressed the test score on the rank of school, the 
age-based measure of the tracking policy and the interaction of the rank with the policy measure. If tracking produces a steeper gradient, the estimated coefficient on the interaction term should be positive. As the last line of Table 2 shows, this is the case. Countries with stronger tracking policies sort students among schools in ways that produce greater differentiation in average test scores among schools.

The variance in test scores among schools in countries that do not track students before age 15 cannot be associated with explicit tracking policies. To be sure, not all of the variance in test scores among schools in these countries will be due to true school impacts on students, but the school fixed effects in these countries should be more reflective of true school impacts than the school fixed effects in countries with early tracking policies. Subtracting the maximum estimate of the effect of tracking on the variance of test scores in Table 2 - the 14 point impact in the single variate regression - from the Table 1 estimated impact of school fixed effects on the variance of test scores of $62 \%$ would reduce the fixed school share of the variance in test scores among students to $48 \%$. This still leaves schools as the major factor associated with student test scores.

\section{B) Other Sources of Sorting}

Per the discussion of sorting earlier, students may sort among schools through mechanisms beyond national tracking policies and thus contribute to school fixed effects. Some countries allow parents greater choice in their enrollment. Schools may have selective admission policies, limiting enrollment to high performing students. Parents may affect student placement by residing in areas with reputedly higher quality schools.

The PISA principals' questionnaire contains three questions which allow us to assess the potential impact of these forms of selection on the estimated school fixed effects. The first question relates to the governance of schools. It asks whether the school is public or private. Private schools are defined as "schools managed directly or indirectly by a nongovernment organization (e.g. a church, trade union, business, or other private institution)". The PISA database also provides information on the sources of funding of the school. Following Woessmann (2009) we classify the public and private sources of school funding ${ }^{28}$. Assuming that families with more academically able students get their children into schools with stronger academic reputations, which in some countries are private institutions, we expect a positive association between private schools and test scores and, assuming those schools have greater homogeneity of students than others, a smaller coefficient of variation

28 Specifically, we classify as public funding the share of funding provided by the "Government (includes departments, local, regional, state and national)" and as private the funding provided by the remaining categories ("Student fees or school charges paid by parents", "Benefactors, donations, bequests, sponsorships, parent fund raising" and "Other"). 
than in other schools. ${ }^{29}$ The second question, extracted from the school principals' questionnaire, is "how often is a student's record of academic performance (including placement tests) considered when students are admitted to your school?" Schools that take account of performance in admissions policy should have a more homogeneous student body and correspondingly lower variance of scores within the school than other schools.

The PISA has a third question regarding school policies that has a more ambiguous relation to the variance of school test scores. It asked principals "How often is residence in a particular area considered when students are admitted to your school?" If residence ${ }^{30}$ is a strong factor in admission, a school will likely admit nearly all students in its catchment area - the less able as well as the more able, and thus be less selective on academic performance, producing greater within school variance in test scores and smaller variance in school fixed effects. On the other side, if wealthier and more educated families live in different catchments than poorer and less educated families, such a policy would increase the variance in school effects. If families with more academically able students move to areas with better schools, the dependence of residence on schools would add yet another sorting contribution to the variance of scores among schools. Section A2 in the appendix describes how we used the PISA questions to construct the variables that we use in ensuing regression analysis.

Table 3 examines the relation between these potential contributors to test scores and variation of scores within schools in two steps. The column labeled "share of schools with practice" shows that almost $2 / 3^{\text {rd }} \mathrm{s}$ of the schools in the sample are in countries with tracking systems that move students to a higher level of school before the age 16 ; that $18 \%$ of the schools are private; that $30 \%$ report selective admissions; and that $35 \%$ report giving heavy weight to enrolling students in the relevant geographic area.

The regression coefficients show the estimated impact of the various policies on three outcome measures: the average test score of a school (column 1), school fixed effects, which is the average score corrected for the characteristics of students (column 2) and the coefficient of variation in test scores within a school (column 3). The index of tracking (a country-level policy) has strong and consistent effects for all the variables. It raises school test scores and the estimated school fixed effect and reduces the within school variation of scores - just what a tracking system should do. The private school variable has negligible insignificant effects and is not a major determinant of outcomes globally, though private schools may have substantial positive or negative relations to outcomes in some countries. The second most powerful statistical relationship is for the selective admissions policies,

29 Given differences in the management and funding of private and public schools across countries, this expectation may hold only in part of the sample.

30

In order to further examine the sorting mechanism through residential location the empirical analysis has been carried out for a finer set of countries. These four countries do not have national tracking policies but two are more egalitarian (Finland and Norway) whereas in the other two residential sorting appears to play a more important role (United Kingdom and United States). Results related to this analysis are available from the authors upon request. We also acknowledge the fact that other sorting mechanisms may play an important role (e.g., parental choices related to public vs. private schools). 
which like national tracking increases school test scores/estimated school fixed effects variables while reducing the coefficient of variation of within-school test scores. ${ }^{31}$ Finally, the selective residence variable is associated with lower test scores/school fixed effects but has no effect on within-school variance. Measuring the share of variation in school fixed effects explained by the four sorting mechanisms as the difference in $\mathrm{R}^{2}$ between the school fixed effects equation (2) with and without the four sorting mechanisms suggests that those factors account for a negligible amount of the variance in the fixed effects: dropping the variables reduces the $\mathrm{R}^{2}$ by just 0.007 points. Still, the PISA questions are sufficiently weak and incomplete measures of sorting across schools, that the Table 3 analysis does not rule out sorting having larger contributions to the school fixed effects in the PISA test data. ${ }^{32}$ Moreover, for readers interested in sorting per se, our analysis leaves out a completely different channel of sorting: the assignment of students with differing abilities and interests to classes within schools (which is substantial in Canada and the United States (Oakes 2005)), that may affect the average level of scores and variance of scores within schools. For our purposes, the safest conclusion is that analysis of observable factors relating to the sorting of students among schools leaves a large variation in school fixed effects that could potentially reflect differences in school policies and practices, to which we turn next.

\section{C) School Policies and Practices}

This section seeks to identify specific school-level policies and practices associated with the substantial role of school fixed effects in the variance of student test scores found in Table 1. We choose the words "associated with" rather than causes or determines because policies and practices are chosen by schools, for reasons about which the PISA provides no insight, rather than being randomly assigned by researchers or some natural experiment. This means that correlations could result not only from the effect of the policies/practices on test scores but also from the effect of test scores (or unmeasured attributes of students or schools associated with those scores) on selection of policies. Finding that certain policies/practices are highly related to test scores while others are not suggests directions for further work and areas for policy consideration. To the extent that schools select policies that work for their students, positive associations between policies and scores should reflect positive linkages in both ways and thus at the minimum identify the likely effect of the policy on scores.

The 2009 PISA data on school policies and teaching practices offer what is arguably the best cross-country school-based data to identify policies that work and that do not. PISA 
obtains information on policies and practices from two sources. First, from principals who report on the presence of a large number of school characteristics and policies. ${ }^{33}$ Second, from students who report on the way they were taught in school. If either or both of these sets of information are related to the estimated school effects that dominate the PISA test scores we would have suggestive evidence that policies and practices matter and (conditional on likely dual causality) the ones that appear most promising for improving school performance.

Table 4 presents our analysis of the effect of school level policies or practices on the school fixed effects test scores for the 17,252 schools in the PISA data set. The column labeled "Measures of School Policies or Practices" gives the specific policies and practices on which we focus. For ease of analysis, we grouped the school policies into three areas: school selectivity, school autonomy and accountability; and school resources, in which we include the attributes of teachers; and grouped the measures of practices into approaches to teaching, reported by students; and staff attitude, reported by principals. Section A2 in the appendix provides the details on the questionnaire items we used.

For starters, the PISA data shows substantial differences in school policies and practices across countries as well as within countries (see Appendix Table A3). Principals in schools in Asian countries report having greater autonomy over curriculum and assessment but lower autonomy over resource allocation compared to principals in the OECD countries. Asian principals also report having greater instructional material, laboratory equipment and availability of computers and software for instruction and higher extra-curricular activities. Nearly 72 percent of Asian principals report academic selectivity in admissions compared to 33 percent of principals in the OECD countries ${ }^{34}$. And nearly all the Asian principals report that their teachers are fully certified with college degrees compared to 84 percent of the principals in the advanced OECD countries. Another major difference between these countries are that 44 percent of principals in OECD countries report that they are evaluated by achievement data and 43 percent report using achievement data to evaluate school teachers. These numbers exceed the 18 percent of principals in Asian countries who say achievement data is used in their evaluations and the 34 percent who say they use it to evaluate teachers.

On the student side, questions regarding the extent to which students relate new information to prior knowledge and knowledge acquired in other situations, which PISA summarizes in an index of elaboration, is significantly lower in Asian countries. In addition,

33 We acknowledge the fact that there may be some measurement error or limited variability in some policy variables (e.g., Dustmann et al. 2012). We also acknowledge the fact even though we tried to focus on those policies that are regarded as important determinants of educational attainment we are aware of the fact that we are not able to account for all the existing policies. We also looked closely at other sources (e.g., World Bank-Saber database, Eurydice reports) but given the nature of our database that includes both developing countries and advanced economies we could not find further consistent and comparable policy information.

By contrast, 8 percent of Asian schools report ability grouping between classes within schools compared to 11 percent of schools in OECD countries. 
to our surprise Asian students report less use of memorization than their OECD counterparts. The index of control of learning strategies consists of techniques used by students to assess the effectiveness of their learning. It includes activities such as understanding of what students need to learn, as well as self-supervision of learning and comprehension checks. It is on average higher among the OECD countries.

To see if any of these policies or practices affects test scores, we estimated equation (1) with inclusion of variables for the policies and practices in place of school dummy variables, and with country dummy variables to pick up the large cross-country variation in the data.

Column 1 in Table 4 gives the regression coefficients linking the average school test scores to the policy and practice variables. Column 2 gives the coefficients for a similar equation linking the variation in test scores within schools on the policy and practice variables. Analyzing the two columns together provides a way to probe potential causal links. For instance, factors associated with higher test scores and lower within-skill variability are likely to reflect sorting as well as other factors; while factors that affect levels of test scores but not the coefficient of variation are more likely to reflect the impact of practices or the effect of test scores on the choice of policy.

The results on academic selectivity policies of schools reproduce the pattern in Table 3: higher test scores and smaller within-school variance of scores for selective schools. The measure of within-school grouping of students by ability between classes also has opposite effects on the average test score and its variance but it reduces the average test score and increases within-school variance. Such a pattern could result from such groupings harming the lower-ability students by reducing their opportunity to learn from peers. But the pattern could also reflect the endogenous decision of schools to sort students by ability. Schools with weaker student bodies might be more likely to separate the more able from the rest. The PISA data do not allow us to differentiate these interpretations.

The coefficients for the school autonomy and accountability variables show some associations between policies and the level of scores (column 1) but essentially no relation between policies and the within-school coefficient of variation (column 2). The key positive relation for the level of test scores is in whether or not a school publicly posts information on student achievement data. $^{35}$ The biggest negative relation is in using achievement data to evaluate principals, which may reflect school authorities relying more on achievement when schools are performing poorly than any adverse effect of this policy on educational outcomes.

The coefficients on the measures of school resources show that variables that reflect greater resources are positively associated with levels of scores and weakly negatively

35 The achievement data includes "aggregated school or grade-level test scores or grades, or graduation rates" (PISA 2009, School Questionnaire, p.20). 
associated the dispersion of scores. The most striking association is for the student to teacher ratio, which has a significant negative coefficient on test scores and significant positive coefficient on the variance of scores. Noting that the PISA measure is students/teachers rather than the more common teacher/student ratio, these results support the STAR finding that higher teacher student raise average performance rather than the negligible relationship found in the bulk of the literature cited earlier. A one SD change in the student-teacher is associated with a $0.03 \mathrm{SD}$ change in the test score. That higher teacher student ratios also reduce the variance of scores makes it a 'win-win" in this context.

The most striking results in the table relate to the association between student reports on "Approaches to Learning" and test scores. These are the strongest and most consistent patterns in the table. Memorization and use of elaboration are associated with low test scores (a one SD increase in memorization is associated with a 0.17 SD reduction in test scores; a one SD increase in elaboration is associated with a 0.09 SD reduction in test scores); whereas use of comprehension checks are associated with higher test scores (a one $\mathrm{SD}$ increase is associated with $0.27 \mathrm{SD}$ increase in test scores). There are two possible reasons for such strong relations. One possibility is that teaching practices that stress comprehension rather than memorization produce better results on the PISA tests that stress use of knowledge in practical settings. The other possibility is that the correlation reflects schools with better students eschewing memorization and elaboration techniques in favor of comprehension checks. With respect to the within-school variance of test scores, the estimated coefficients show that: memorization and elaboration are associated with greater variation while comprehension checks are associated with lower variation. Finally, there are no clear patterns in the relations between the principal reports of staff attitudes and test scores or variance in scores within schools.

To get a better sense of the robustness of the estimated patterns across countries with different tracking policies, we divided the sample into groups: schools in countries with a tracking system (defined by the dichotomous tracking variable described in section 4A) and those without such a system. Since schools without tracking deal with more heterogeneity in their student bodies, they are likely to rely on the policies and practices listed in the table than those with tracking, possibly with different effects. In fact test scores in the schools without tracking appear to be more responsive to policies than test scores in schools with tracking and sometimes with differently estimated signs on the variables. For instance, the posting test score variable has a large positive effect for schools without tracking compared to a smaller insignificant for schools with tracking while four of the measures of school resources obtain statistically significant coefficients for the non-trackers compared to a single measure - the student-teacher ratio - for schools with tracking. The overall pattern shows up in the noticeably higher R-squared in the column 3 regression than in the column 4 regression. Whether the causal pattern runs from the test scores to the policies or from the policies to the test scores, the differences between the two groups are a warning sign that 
similar policies may be associated with different outcomes depending on other characteristics of the school system and country.

One set of variables in Table 4, however, shows no relation between schools in countries with tracking and schools in countries without tracking. This is the "approaches to learning" variables that measure the way students say they are being taught. Here, the variables have similar highly significant effects regardless of national tracking policies. This robust result suggests that the mode of teaching may be the key to understanding the strong school effects in the data. Future research into school practices may profit from investing more in obtaining student views of how the school operates than in giving extended questionnaires to principals.

A parallel way to examine the extent to which school fixed effects are associated with what schools do as opposed to the sorting of students among schools is to examine directly the link between estimated fixed effects and policies and practices. To do this we run the following regression:

$$
\beta_{3 \mathrm{sc}}^{\prime}=\alpha_{1} \mathrm{~S}_{\mathrm{sc}}+\varepsilon_{\mathrm{sc}}
$$

where $\beta_{3 \mathrm{sc}}^{\prime}$ is the vector of estimated fixed school effects for school $\mathrm{S}$ in country $\mathrm{C}$ and $\mathrm{S}_{\mathrm{sc}}$ is the vector of school policies and practices in school $\mathrm{S}$ in country $\mathrm{C}$.

Table 5 summarizes the results from estimating variants of equation (3). Since the estimated coefficients on specific policies and practices are similar to those in Table $4,{ }^{36}$ the table gives the residual variances from the regressions and the summary R-squared statistics for different specifications. These estimates tells us the extent to which the whole set of policies and practices help explain the fixed effects. The line labeled school fixed effects gives the total variance in the estimated fixed coefficients. Line 1 shows that with no other variables in the equation, the vector of policies and practices by itself accounts for $44.3 \%$ of the variance. Line 2 shows that the country dummies account for $52.6 \%$ of the variance in the fixed effects while line 3 shows that addition of the vector of policies and practices raises the R-squared to $63.9 \%$. That is the policies and practices explain $23.8 \%$ [ $=(0.639-0.526) /$ (1-0.526)] of the variance beyond that associated with country differences.

The remaining lines in the table explore the effects of adding school-level covariates to these calculations, where the covariates are average levels of student attributes as defined in the table note. Line 4 shows that these attributes by themselves account for $21.4 \%$ of the variance. Addition of policy and practices in line 5 raises the R-squared to 0.583 , so that policies and practices explain $46.9 \%[=(0.583-0.214) /(1-0.214)]$ of the variance beyond that associated with other school level factors. Finally, lines 6 and 7 shows that addition of 
school policies and practices to regressions with covariates and country dummies raises the R-squared from 0.579 (line 5) to 0.708 , so that policies and practices explain $30.6 \%$ [ $(0.708-0.579) /(1-0.579)]$ of the variance beyond that associated with other school level factors and country dummies.

In sum, the calculations in Table 5 show that fixed school effects are sufficiently related to school practices and policies to reflect more than sorting of students. Lacking exogenous variation in policies and practices to separate the link from the policies and practices to test scores from the endogeneity of policies and practices to student attributes associated with test scores, we cannot determine the magnitudes of the policy factors on school level test scores. What the association between the fixed effects and policies and practices does is to direct attention to school effects and decisions as opposed to sorting of students in explaining the variance of test scores and thus in developing school-level policies to improve scores.

\section{School Effects and Family Background}

As noted in the section 2 literature review, studies invariably find that family background factors are strongly associated with student performance in schools and test scores. Table 1 showed that background factors by themselves explained $33 \%$ of the variance in test scores among all students and explained from 14\% (Asian countries) to $29 \%$ (EU15) of the variance in test scores within country groups. Given the large role of the school which students attend in the variance of test scores, we ask the extent to which, if at all, the schools which students attend mediate the relation between family background and student test scores. The answer is a surprisingly large extent.

The PISA contains three potential measures of family background: ${ }^{37}$ the education of their parent, ${ }^{38}$ the number of books in the household, ${ }^{39}$ and a composite "index of socioeconomic and cultural status" (ESCS) ${ }^{40}$ developed by PISA Students report on their parents education and on the number of books in their household. PISA calculates the ESCS based on the level of parental education converted into years of schooling, ${ }^{41}$ an index of parental occupation, an index of family wealth, cultural possessions, home educational resources, and an index of home possessions, which includes the variable number of books at home.

This variable comes from students' responses to a question about the number of books in their home exclusive of magazines, newspapers and schoolbooks. Students can choose one of the six categories: 0-10, 11-25, 26-100, 101-200, 201-500, more than 500 (PISA 2009, Student Questionnaire, question n. 22).

40 mean of 0 and a standard deviation equal 1 .

The variable is derived from the student questionnaire, in which PISA asks students the highest level of schooling completed by their father/mother and whether their father/mother have completed undergraduate or postgraduate degrees. 
Table 6 records the mean and standard deviation (in parentheses) of these variables among students in all PISA countries and in the five groupings that we have examined. The means for the different groupings show variation in the levels of the background variables while the standard deviations show variation within the country groupings. Students from Asian countries have a higher share of parents who have completed higher education (39\%) compared to the students in the OECD countries (31\%). Parental education is almost always positively associated with better school performance by children. ${ }^{42}$ Asian students taking the PISA tests also report that living in families with more books than students in OECD countries: $43 \%$ of Asian students live in families with more than 100 books compared to $34 \%$ of students in the OECD country sample. The ESCS index gives students in the EU15+ the highest score and students in middle income countries the lowest scores.

We have examined the mediating role of school fixed effects in the relation between each of the measures and test scores by estimating variants of equation $1 .{ }^{43}$ We first estimated the effect of a given background factor with no measure of school effects in the equation and then estimated the equation with the inclusion of fixed school effects. ${ }^{44} \mathrm{We}$ obtained similar results for each of the three background measures. ${ }^{45}$ For simplicity we summarize our findings for the ESCS variable, which has the virtue of encompassing parental schooling and books at home measures of background.

Table 7 gives results for all countries and for countries with early tracking policies and countries without them, the better to isolate effects within school unrelated to tracking. Results for particular country groupings are available from the authors. The table records coefficient on the ESCS measure of background and the $\mathrm{R}^{2}$ associated with the regression of test scores on the variables specified in the row and in the table note. Row [1] records the estimated coefficients on family background with country fixed effects as the only covariate so that the analysis focuses on within-country variation in test scores. Row [2] includes a set of student-level and a set of school-level controls that reflect in addition differences in the urban location and size of schools across countries (see Appendix Table A1). In both rows the coefficients of family background are large and significant. In row 1 for the all country sample, a one-SD change in the ESCS index is associated with a 0.36 SD change in test scores. The addition of background and school control variables reduces the estimated size

Some analysts argue that parents education increases the marginal productivity of children's education, by raising expectations about educational success (Davis-Kean 2005, Borjklund and Salvanes 2010) but it can also operate through the higher income associated with higher parental education.

43 This production function approach is commonly used in the literature (Hanushek and Woessmann 2011a). The main underlying assumptions are related to the fact that the production function is known and inputs are used to maximize student learning outcomes. Hanushek $(1979,1986)$ ) describes some of its limitations. Schuetz et al. (2008) note that country-specific results may be affected by

44 the measurement of background factors.

Dustmann et al. (2012) used a similar approach to examine the effect of school resources, class size and accountability on the gap in learning outcomes among migrant and native students in PISA 2006.

45 These results are available from the authors upon request. 
of the ESCS effect to 0.28 SD. But it is in row [3], where we add the school dummy variables that the coefficients on the ESCS background measures drop greatly. For all countries, the coefficient drops from 24.20 to 10.28 - a 58 percent fall. The effect size falls to 0.16 SDs. While the extent of the decline differs among the groups, the calculations in ensuing columns show that it is large in all cases. ${ }^{46}$

PISA contains an alternative set of measures designed to case light on the relation between family background and test scores. Fourteen countries ${ }^{47}$ in the 2009 wave of PISA practices administered a parent questionnaire that asked about parenting practices relevant to education. ${ }^{48}$ The OECD analysis of these questions (OECD 2012b) shows that parental activities are positively correlated with test scores but that specific activities with the child have different relations to outcomes. A parent discussing what their child is doing is positively related to test scores whereas a parent discussing their child's progress in school with a teacher is negatively related to test scores, presumably because the parent is responding to the student not doing that well in school. The OECD also finds that parental involvement is higher in more affluent households. However, it warns that the high nonresponse rate in some countries raises questions about the results (OECD 2012, p.328). ${ }^{49}$

We selected from the parent questionnaire four areas of involvement to examine: early parental investment in children exemplified by questions about how often they read books with the child at an early age; participation in school-related activities such as whether parents participate in the local school governance; provision of resources to the child such as subscription to a journal or magazine; and current activities with the child such as discussing political or social issues with the child. ${ }^{50}$ Row [4] in Table 7 shows the addition of the

46

Table 7 only shows the coefficients related to the family background variables. The complete regression results are available from the authors.

47

These are the countries: Hong-Kong, Korea, Macao-China, Chile, Denmark, Germany, Hungary, Italy, New Zealand, Poland and Portugal. The parent data file includes the variables derived from the parent context questionnaire (OECD (2012), "PISA 2009 Technical Report", Paris: OECD Publishing, p.328). The Parent Questionnaire of the PISA 2009 study was delivered to parents by students who had to return it to school once it had been filled in. At page 2 of the Parent Questionnaire it is explained that "This survey should be completed by a parent (or jointly by both parents) or other < primary caregiver> of the student".

PISA 2006 also included some parent questions. Before the 2006 and 2009 waves, cross-country data sets of student performance did not provide much information on parents' participation in home and school-related activities.

49 Some bias may also be generated by the design of the survey: better educated parents may be more likely to fill this optional questionnaire and more diligent students - with higher test scores - may be more likely to bring the questionnaire home, remember to ask their parents to fill it and after to return it to school (OECD, p.91). In this regard, descriptive statistics presented in the OECD study (2012b, p.163) [OECD (2012) "Parental Involvement in Selected PISA Countries and Economies" OECD Education Working Paper No. 73 - working paper prepared by F. Borgonovi and G. Montt] carried out for the entire PISA 2009 sample and for the sample of students who answered the parent questionnaire show a significant heterogeneity in terms of response rate across countries. Apart from Poland where the questions on parental involvement were not asked (OECD 2012, p.50), the response rate varies from about $100 \%$ in Macao-China to about $60 \%$ in Denmark. There are also some differences in terms of demographic characteristics. Students in the sample with answers to the parent questionnaire have on average better reading performance, a higher socio-economic status, are more likely to be a girl and less likely to be of immigrant status. Moreover, a difference between the information on parents' education as reported by students and parents themselves should be acknowledged, being information selfported by parents on average than the one reported by their children (Jerrim and Micklewright 2012).

We use indexes based on the parents' answers to the questions in each area available in the PISA database: Early Parental Involvement Index of activities with the child (when the child attended the first year of ISCED 1); Current Parental Involvement Index of current activities with the child; Parent Participation in School Related Activities Index of participation in school related activities; Resources Directly Available to the Child Index of resources available to the child. Section A2 in the appendix provides a detailed description of the indexes, items in the questionnaires on which they are based and how they have been constructed. The 
parental involvement indexes had a modest effect on the estimated impact of the ESCS background measure overall, decreasing it among OECD countries to an estimated effect size of 0.09 of a standard deviation, while increasing the background coefficient among Asian countries. ${ }^{51}$ It does not have the consistent effect on the estimated background effect that the schooling fixed effects have. ${ }^{52}$ Measured school policies and practices have a greater effect in mediating the influence of background on test scores than measured parental involvement activities.

\section{Conclusion and Policy Implications}

Our analysis of the 2009 wave of the PISA data set has found that much of the variation of test scores is associated with the school students attend and that school fixed effects are a major pathway for the link between measures of family background and test scores.

Within the limits of observational data, we estimated the extent to which the variation in student performance across schools reflects mechanisms that sort students into different types of schools as opposed to the relation between school policies/practices and student performance. We examined national policies toward tracking students at different ages, school policies toward selective admissions and toward admissions based on residency and between private and public schools and found that while greater sorting by country or school raised the variance of test scores among schools and lowered variance of test scores within schools, measurable sorting leaves a sizable proportion of school fixed effects for school educational policies and practices to affect student performance and thus for policies and practices to improve student test scores.

Using the reports of principals and students on the PISA, we examined the association between explicit policies/practices and the test scores of students attending different schools. Consistent with our analysis of sorting, the full set of measured policies and practices accounted for a sufficient proportion of the school fixed effects to support the view that policies and practices can affect test scores in important ways. We found that several policies, particularly those relating to school resources, were significantly associated with

PISA 2009 Technical Report explains the computation, scaling methods and weights involved in the construction of the indexes (OECD 2010d, 2012a). The PISA variables represent a limited selection of the many aspects and activities that shape the relationship between parents and children and could impact on the students' learning progress. Descriptive statistics related to the parental involvement variables are available from the authors upon request.

Rows 1-3 include all countries in the specified group. Row 4 includes only the 14 countries where the parental questionnaire was administered. Regressions in rows 1-3 have also been estimated with the same sample as in row 4. Results show that parental involvement has only a limited impact in reducing the ESCS coefficient for all country groups. These additional results together with e results for specific groups of countries are available from the authors upon request.

Our findings suggest that measures of parental practices do not account for much of the parental background factors. Instead the major factor that reduces the impact of background factors on outcomes are school fixed effects. It is important to notice that given the structure of the PISA database we are able to control for a limited number of family background characteristics and parental practices and we are not able to control for the unobserved parental characteristics. Therefore, given the existing asymmetry of our analysis we are not able to draw conclusions on the role that unobserved parental characteristics correlated with school fixed effects may play in affecting outcomes. 
test scores, though some had differing effects on schools with different tracking policies, highlighting the potential for the same policy to have different effects in different settings. Since principals undoubtedly differ in how they implement policies across countries and within countries, we believe that new PISA questions on implementation would increase the proportion of the test score variance associated with policies and practices.

Our analysis of the role of sorting as opposed to within-school policies and practices has implications on the continual debate regarding these alternative ways of improving educational outcomes. As we saw in the literature review, much research using crosscountry data focuses on the effects of explicit national tracking on outcomes while recognizing that other mechanism also sort students with particular abilities into schools with students like themselves. Our data shows that, taking sorting as given, there is still a large space for school level policies and practices within sorting regimes. Schools in countries which track students early and schools that admit students with greater selectivity show substantial school effects independent of the sorting and measured student attributes. Within sorting groups, moreover, schools operate with different policies and practices, some of which are associated with different test score outcomes that suggests substantial potential for improvements in scores within sorting groups.

Our table 4 analysis found that while the approaches to learning practices are associated with students' test scores in a similar way between groups of countries with tracking and those without tracking, as defined in the tracking literature, other policies such as those relating to school autonomy and accountability are associated with test scores differently in tracking than in non-tracking environments. To the extent that these effects reflect the differential impact of policies on students, they direct policy attention at the value of developing different school policies depending on the extent of national tracking. Reducing school autonomy in countries without sorting is associated with poorer performance while it has modest negligible effects in countries with sorting. The key policy implication is that the choice of some within school policies and practices should be considered differently depending on sorting and that international evidence that something works in a system with tracking cannot be taken as indicative that it will work in a system without tracking.

The biggest problem in analyzing the PISA evidence is unpacking the causality of the observed associations: the extent to which they reflect the effect of policies on test scores or of student performance and attributes on policies. We suggest that the best way to untangle this is to address it directly on the principals' questionnaire: to add a set of questions asking when and why a policy was adopted and whether the school had assessed it through some sort of before/after or other analysis. If school policies matter and effectiveness depends on implementation, the best way for international tests to move from measuring outcomes to helping devise reforms in schooling would be to measure these factors at the school level.

The strongest and most consistent relation between policies and practices in the PISA data was not however, based on principal reports but on student reports on teaching practices 
at their school. The strength and consistency of the relation between student reports and school test performances suggest that the most promising way for PISA and other international surveys to increase our understanding of school effects would be through obtaining more information about school experiences from students themselves. A set of questions to students on school practices and individual experiences would offer a new line of sight into what goes on in schools that actually affects student performance.

Following this line of thought, the PISA (or other surveys) could illuminate sorting mechanisms by asking students or parents about why the student was attending the current school and how they were admitted. Bratti and Checchi's (2013) finding in an analysis of a Italian re-test of schools in the 2009 PISA that cross-sectional test scores were good measures of changes in student performance when student attrition was low but bad measures when student attrition was high suggests the value of questions on how long students were in a given school.

While it can only be suggestive for directions of policy reforms, our analysis of the school fixed effects in the PISA data suggests that policies related to the quality of educational resources and practices at the classroom level are good candidates for improvements in performance. We suspect that the reason they turned out to be strongly linked to school test performances is that they are closer to actual classroom activities than some of the accountability and autonomy managerial practice questions and to the parental activity questions on which the PISA focused. Still, even finding avenues for improvement does not itself justify schools seeking those reforms. It is necessary as well to estimate the cost of the reforms (Hanushek and Woessmann 2011b) and the length of time it takes for reforms to become effective (Braga et al. 2013).

Still, given the great success of PISA in discussion of educational outcomes around the world and its influence on policies, we believe that improving it in ways that will better illuminate school effects and help identify the causal forces behind those effects has the potential for catalyzing school level reforms that could improve the performance of poorer performing schools and reduce the magnitude of the schools fixed effect that we found in the 2009 PISA. 


\section{REFERENCES}

Algan Y., P. Cahuc and A. Shleifer (2013) "Teaching Practices and Social Capital”, American Economic Journal: Applied Economics, 5(3): 189-210.

Altinok, N., Kingdon, G., (2012) "New Evidence on Class Size Effects: A Pupil Fixed Effects Approach", Oxford Bulletin of Economics and Statistics, 74(2): 203-34.

Altonji, J.G., Elder, T.E., Taber, C.R., (2005), "Selection on observed and unobserved variables: Assessing the effectiveness of Catholic schools" Journal of Political Economy, 113 (1), 151-184.

Ammermueller, A., Heijke, H., Woessmann, L., (2005) "Schooling quality in Eastern Europe: Educational production during transition" Economics of Education Review 24 (5): pp. 579-99.

Angrist J., E. Bettinger, E. Bloom, E. King, and M. Kremer (2002) "Vouchers for Private Schooling in Colombia: Evidence from a Randomized Natural Experiment" American Economic Review, 92(5): $1535-1558$.

Betts J.R. (2011) "The Economics of Tracking in Education" in E.A. Hanushek, S. Machin and L. Woessmann (eds.), Handbook of the Economics of Education, Vol.3, The Netherlands: North-Holland, Chapter 7.

Betts J.R. and J.L. Shkolnik (2000), “The effects of ability grouping on student math achievement and resource allocation in secondary schools", Economics of Education Review 19: 1-15.

Bietenbeck J.C. (2011), “Teaching Practices and Student Achievement: Evidence from TIMSS”, Master Thesis CEMFI No. 1104.

Bishop, J.H. (1997). "The Effect of National Standards and Curriculum-Based Exams on Achievement." American Economic Review, 87: 260-264

Bishop, John H. 2006. "Drinking from the Fountain of Knowledge: Student Incentive to Study and Learn Externalities, Information Problems, and Peer Pressure." In Handbook of the Economics of Education, edited by Eric A. Hanushek and Finis Welch. Amsterdam: North Holland: 909-944.

Bjorklund A. and K.G. Salvanes (2010) "Education and Family Background: Mechanisms and Policies, IZA Discussion Paper No. 5002.

Bjorklund A. and K.G. Salvanes (2011) ("Education and Family Background: Mechanisms and Policies", Handbook of the Economics of Education, Chapter 3.

Bourdieu, P. (1986). "The forms of capital" (R. Nice, Trans.). In J. C. Richardson (Ed.), Handbook of theory and research for the sociology of education (pp. 241-258). New York: Greenwood Press.

Braga M., D. Checchi and E. Meschi (2013), "Educational Policies in a Long-Run Perspective", Economic Policy, 28(73): 45-100.

Bratti M. and D. Checchi (2013), "Re-testing PISA Students One Year Later: On School Value Added Estimation Using OECD-PISA", IZA Discussion Paper No. 7722.

Bratti M., D. Checchi and A. Filippin (2011) "Should you compete or cooperate with your schoolmates?", Education Economics, 19(3): 275-89.

Brunello G. and D. Checchi, (2007) "Does school tracking affect equality of opportunity? New international evidence", Economic Policy 22 (52): 781-861.

Brunello G. and M. Schlotter (2011), "Non Cognitive Skills and Personality Traits: Labour Market Relevance and their Development in Education and Training Systems", IZA Discussion Paper No. 5743.

Chingos M.M. and G.J. Whitehurst (2011), "Class Size: What Research Says and What it Means for State Policy" http://www.brookings.edu/research/papers/2011/05/11-class-size-whitehurst-chingos

Coleman, J. S. (1988). "Social capital in the creation of human capital", American Journal of Sociology, 94 (Supplement): 95-120.

Costa P.T. Jr., and R.R. McRae (1992), "Revised NEO Personality Inventory (NEO-PI-R) and NEO FiveFactor Inventory (NEO-FFI) professional manual”, Odessa, Florida: Psychological Assessment Resources, Inc.

Davis-Kean P.E. (2005), "The influence of parent education and family income on child achievement: The indirect role of parental expectations and the home environment", Journal of Family Psychology, 19:294-304.

Desforges, C. and A. Abouchaar (2003), “The Impact of Parental Involvement, Parental Support and Family Education on Pupil Achievements and Adjustment: A Literature Review", Department for Education and Skills, Nottingham.

DiMaggio, P. (1982), "Cultural capital and school success: The impact of status culture participation on the grades of U.S. High School Students", American Sociological Review, 47: 189-201.

Dolton P. (2006) "Teacher Supply" in E.A. Hanushek and F. Welch (eds.) "Handbook of the Economics of 
Education," edition 1, (2): 2, Ch. 19.

Dronkers J. (1992), "Parents, love, and money: The relations between parental class, cognitive skill, educational attainment, occupation, marriage, and family income", International Perspectives on Education and Society", 2: 277-93.

Dustmann C., T. Frattini and G. Lanzara (2012), "Educational achievement of second-generation immigrants: an international comparison", Economic Policy 27(69): 143-85.

Epple D. and R. Romano (1998) "Competition between private and public schools, vouchers, and peer group effects" American Economic Review 88(1): 33-62.

Figlio, David N., Marianne E. Page (2002), 'School Choice and the Distributional Effects of Ability Tracking: Does Separation Increase Inequality?", Journal of Urban Economics 51(3): 497-514.

Freeman R.B., S. Machin and M. Viarengo (2011) "Inequality of Educational Outcomes: International Evidence from PISA", Regional and Sectoral Economic Studies, Vol.11, No.3.

Fuchs, T., and L. Woessmann. (2007), "What accounts for international differences in student performance? A re-examination using PISA data." Empirical Economics 32(2-3): 433-62.

George, R., and Kaplan, D. (1998), "A structural model of parent and teacher influences on science attitudes of eighth graders: Evidence from NELS: 88”, Science Education, 82: 93-109.

Greene, J. P. and M. Winters (2005) 'Public high school graduation and college readiness: 1991-2002", New York: Manhattan Institute for Policy Research.

Hanushek E.A. (1979), "Conceptual and empirical issues in the estimation of educational production functions", Journal of Human Resources 14 (3, Summer): 351-388.

Hanushek E.A. (1986), "The Economics of Schooling: Production and Efficiency in Public Schools”, Journal of Economic Literature, 24 (3, September): 1141-1177.

Hanushek, E.A., (2006), "School Resources", In: Hanushek, E.A., Welch, F. (Eds.), Handbook of the Economics of Education. North Holland, 865-908.

Hanushek, E.A. and Raymond, M.F (2003). "Lessons about the Design of State Accountability Systems", in: Paul E. Peterson and Martin R. West (eds). No Child Left Behind? The Politics and Practice of Accountability, Washington, DC: Brookings, 127-51.

Hanushek, E.A. and Rivkin, S. G. (2006): "Teacher quality," in E. A. Hanushek, and F. Welch (eds) Handbook of the Economics of Education, 1: 1050-78. North Holland, Amsterdam.

Hanushek, E.A., Woessmann, L. (2006), "Does educational tracking affect performance and inequality? Differences-in-differences evidence across countries", Economic Journal 116 (510): C63-C76.

Hanushek E.A. and L. Woessmann (2011a), "The Economics of International Differences in Educational Achievement" in E.A. Hanushek, S. Machin and L. Woessmann (eds.), Handbook in Economics, Vol.3, The Netherlands: North-Holland, 89-200.

Hanushek E.A. and L. Woessmann (2011b), "Educational Outcomes" Economic Policy, July, pp. 427-91.

Hanushek E.A., S. Link and L. Woessmann (2013), "Does School Autonomy Make Sense Everywhere? Journal of Development Economics, 104: 212-32.

Holmlund H., S. McNally and M. Viarengo (2010) "Does Money Matter for Schools?", Economics of Education Review, 29: 1154-1164.

Hoover-Dempsey, K. V., and Sandler, H. M. (1997). "Why do parents become involved in their children's education?" Review of Educational Research, 67(1): 3-42.

Jackson C. K. (2010) "Do Students Benefit from Attending Better Schools? Evidence from Rule-based Student Assignments in Trinidad and Tobago" Economic Journal, 120(549): 1399-1429.

Jenkins S.P., Micklewright, J., Schnepf, S.V. (2008) "Social segregation in secondary schools: How does England compare with other countries?" Oxford Review of Education 34(1): 21-38.

Jerrim J. and J. Micklewright (2012), "Socioeconomic gradients in children's cognitive skills: Are crosscountry comparisons robust to who reports family background?" DoQSS - Institute of Education Working Paper No. 12-06.

Jurges H., K. Schneider and F. Buchel (2005) "The effect of central exit examinations on student achievement: Quasi-experimental evidence from TIMSS Germany" Journal of the European Economic Association, 3(5): 1134-1155.

Krueger A. (1999) "Experimental Estimates Of Education Production Functions", Quarterly Journal of Economics, 114:497-532.

Lankford L. and J. Wyckoff (2002), "Teacher sorting and the plight of urban schools: A descriptive analysis", Educational Evaluation and Policy Analysis 24(1): 37-62.

Lavy V. (2011), "What Makes an Effective Teacher? Quasi-Experimental Evidence" NBER Working Paper No. 16885. 
Machin S. and S. McNally, (2012) "The Evaluation of English Education Policies", National Institute Economic Review, National Institute of Economic and Social Research, 219(1): R15-R25.

Nechyba T.J. (2011) "Income and Peer Quality Sorting in Public and Private Schools" in E.A. Hanushek, S. Machin and L. Woessmann (eds.), Handbook of the Economics of Education, Vol.3, The Netherlands: North-Holland, Chapter 22.

Oakes J. (2005) "Keeping Track: How Schools Structure Inequality, second ed.”, New Heaven: Yale University Press.

OECD (2005), "Education at a Glance 2005", Paris: OECD Publishing.

OECD (2010a), "PISA 2009 at a Glance", Paris: OECD Publishing.

OECD (2010b), "PISA 2009 Results: What Students Know and Can Do - Student Performance in Reading, Mathematics and Science (Volume I)", Paris: OECD Publishing.

OECD (2010c), "PISA 2009 Results: Learning Trends: Changes in Student Performance Since 2000 (Volume V)", Paris: OECD Publishing.

OECD (2010d), "PISA 2009 Results: What Makes a School Successful? - Resources, Policies and Practices (Volume IV)", Paris: OECD Publishing.

OECD (2012a), "PISA 2009 Technical Report”, Paris: OECD Publishing.

OECD (2012b) "Parental Involvement in Selected PISA Countries and Economies" OECD Education Working Paper No. 73 - working paper prepared by F. Borgonovi and G. Montt.

Ou D. (2010), "To Leave or Not to Leave? A Regression Discontinuity Analysis of the Impact of Failing the High School Exit Exam", Economics of Education Review, 29(2): 171-86.

Peterson, P.E., and Hess, FM (2006) "Keeping an eye on state standards", Education Next 6(3): 28-29.

Peterson, P.E., and Hess, FM (2008), "Few states set world-class standards: In fact, most render the notion of proficiency meaningless" Education Next, 8(3): 70-3.

Peterson P.E. and Viarengo, M., (2011), "Social Capital and School Impacts on the Non-Cognitive Skills of Early Adolescents: Evidence from a National Longitudinal Survey", Chapter 4 in Mark Berends, Marisa Cannata and Ellen B. Goldring, (eds.) "School Choice and School Improvement", Cambridge, MA: Harvard University Press.

Peterson P.E., and Woessmann, L., (2007) "Introduction: Schools and the equal opportunity problem", In: Woessmann, L., Peterson, P.E. (Eds.), Schools and the Equal Opportunity Problem. MIT Press, 3-27.

Peterson P.E, L. Woessmann, E.A. Hanushek and C.X. Lastra-Anadón (2011), "Globally Challenged: Are U. S. Students Ready to Compete? The latest on each state's international standing in math and reading", Harvard's PEPG Report No. 11-03.

Pop-Eleches C. and M. Urquiola (2013) "Going to a Better School: Effects and Behavioral Responses", American Economic Review, 103(4): 1289-1324.

Schoon I., and Parsons, S. (2002), "Competence in the face of adversity: the influence of early family environment and long - term consequences", Children and Society, 16: 260-272.

Schuetz G., Ursprung, H.W., Woessmann, L., (2008), "Education policy and equality of opportunity" Kyklos 61 (2): 279-308.

Schwerdt G. and A.C. Wuppermann (2011): "Is Traditional Teaching Really All That Bad? A Within-Student Between-Subject Approach", Economics of Education Review, 30: 365-79.

Singh K., Bickley, P.G., Keith, T.Z., Keith, P.B., Trivette, P., and Anderson, E. (1995) "The effects of four components of parental involvement on eighth-grade student achievement: structural analysis of NELS-88 data", School Psychology Review, 24(2): 299-317

Sprietsma M. (2008) "Regional school choice and school selectivity: How do they relate to student performance? Evidence from PISA 2003”, European Journal of Comparative Economics, 5(2): 133 156.

West M.R. and L. Woessmann (2006), "Which School Systems Sort Weaker Students into Smaller Classes? International Evidence", European Journal of Political Economy, 22(4): 944-968.

Woessmann L. (2003a), "Schooling resources, educational institutions, and student performance: The international evidence", Oxford Bulletin of Economics and Statistics 65(2): 117-70.

Woessmann L. (2003b), "Central Exit Exams and Student Achievement: International Evidence". In: P.E. Peterson, M.R. West (eds.), No Child Left Behind? The Politics and Practice of School Accountability, Washington, D.C.: Brookings Institution Press, 292-323.

Woessmann L. (2005a). "The Effect Heterogeneity of Central Exams: Evidence from TIMSS, TIMSS-Repeat and PISA", Education Economics, 13(2): 143-69.

Woessmann L. (2005b) "Educational production in East Asia: The impact of family background and schooling policies on student performance", German Economic Review, 6(3): 331-53; Kiel Working Paper No. 
1152.

Woessmann L. (2008), "How equal are educational opportunities? Family background and student achievement in Europe and the United States" Zeitschrift für Betriebswirtschaft, 78 (1): 45-70.

Woessmann L., (2009) "Public-private partnerships and student achievement: A cross-country analysis". In: Chakrabarti, R., Peterson, P.E. (Eds.), School Choice International: Exploring Public-Private Partnerships. The MIT Press, 13-45.

Woessmann L., (2010) "Families, schools, and primary-school learning: Evidence for Argentina and Colombia in an international perspective", Applied Economics 42(21): 2645-65.

Woessmann L., E. Ludemann, G. Schuetz and M. West (2007), "School Accountability, Autonomy, Choice, and the Level of Student Achievement: International Evidence from PISA 2003", OECD Education Working Papers No. 13

Woessmann L., E. Luedemann, G. Schuetz, and M.R. West. (2009) "School Accountability, Autonomy, and Choice around the World", Cheltenham, UK: Edward Elgar. 


\section{TABLES AND FIGURES}

Table 1: Test Scores and Analysis of Variance Decomposition of Test Scores: Country, Family Background and School Effects, PISA 2009

\begin{tabular}{|c|c|c|c|c|c|}
\hline \multirow[b]{2}{*}{$\begin{array}{l}\text { Country Groups }^{7} \\
\text { (Number of countries and students } \\
\text { in parenthesis) }\end{array}$} & \multicolumn{2}{|c|}{ Mean and Variation in Scores ${ }^{1}$} & \multicolumn{3}{|c|}{$\begin{array}{l}\text { Percentage of Variance in Scores due to } \\
\text { Specified Factors }{ }^{3}\end{array}$} \\
\hline & $\begin{array}{l}\text { Average Test } \\
\text { Score } \\
\text { (Standard } \\
\text { Deviation) }\end{array}$ & $\begin{array}{c}\text { Coefficient } \\
\text { of Variation }\end{array}$ & $\begin{array}{l}\text { Country } \\
\text { Effects } \\
\text { (C) }\end{array}$ & $\begin{array}{l}\text { Background } \\
\operatorname{Effects}^{5} \text { (B) }\end{array}$ & $\begin{array}{l}\text { School Effects } \\
\text { (S) }\end{array}$ \\
\hline All $^{8}(74 ; 515,956)$ & $\begin{array}{c}449.47 \\
(104.74) \\
\end{array}$ & 23.30 & 0.322 & 0.334 & 0.618 \\
\hline OECD $(31 ; 249,125)$ & $\begin{array}{l}489.30 \\
(94.54) \\
\end{array}$ & 19.32 & 0.053 & 0.276 & 0.435 \\
\hline EU $15+{ }^{9}(17 ; 150,696)$ & $\begin{array}{l}498.24 \\
(95.23) \\
\end{array}$ & 19.11 & 0.024 & 0.291 & 0.475 \\
\hline Asian $(7 ; 38,095)$ & $\begin{array}{l}540.28 \\
(96.02) \\
\end{array}$ & 17.77 & 0.026 & 0.143 & 0.502 \\
\hline Other High Income $(8 ; 44,384)$ & $\begin{array}{l}465.71 \\
(86.47) \\
\end{array}$ & 18.57 & 0.021 & 0.191 & 0.348 \\
\hline Middle Income $(27 ; 179,366)$ & $\begin{array}{l}388.28 \\
(81.22) \\
\end{array}$ & 20.92 & 0.076 & 0.258 & 0.522 \\
\hline
\end{tabular}

Note: Sampling probability weights have been used in order to provide descriptive statistics representative for each country

${ }^{1}$ Test scores in mathematics here and in the remaining of the analysis unless otherwise specified.

${ }^{2}$ Coefficient of variation $(\mathrm{CoV})$ is a normalized measure of dispersion calculated as the standard deviation divided by the mean score.

${ }^{3}$ Variance has been extracted as the share of test score variation explained by the model (ANOVA $/ \mathrm{R}^{2}$ In the underlying regression test score is a function of country dummies. The figure has been divided by test score variance.

${ }^{4}$ In the underlying regression test score is a function of country dummies. The figure has been divided by test score variance.

${ }^{5}$ In the underlying regression test score is a function of the family background measure, student-level and school-level controls. Here family background has been proxied by the ESCS index. The figure has been divided by test score variance. The ANOVA analysis has also been carried out by using the components of the ESCS unrestrictedly. Results are consistent with the analysis presented here and available from the authors.

${ }^{6}$ In the underlying regression test score is a function of school dummies. The figure has been divided by test score variance

${ }^{7}$ Only a low-income country participated to the PISA 2009 study: Kyrgyzstan, so we did not include this group. The analysis has been carried out for this country and is available from the authors upon request.

${ }^{8}$ This group includes 72 countries and 2 Indian states.

${ }^{9}$ This category includes Austria, Belgium, Denmark, Finland, France, Germany, Greece, Ireland, Italy, Luxembourg, the Netherlands, Portugal, Spain, Sweden and the United Kingdom, Norway and Switzerland. 
Table 2: Estimates on Effect of Country Tracking Practices on Gradient of Effect of Rank-School School-fixed-effects and Percentage of Country Variance in Test Scores, by Country Tracking Practices

\section{Panel A: Country Level Regressions}

\begin{tabular}{|c|c|c|c|c|}
\hline \multirow[b]{2}{*}{$\begin{array}{l}\text { Measure of Tracking in } \\
\text { country } 1\end{array}$} & \multicolumn{2}{|c|}{$\begin{array}{l}\text { Coefficient from regression of gradient of } \\
\text { school test score- school rank on tracking } \\
\text { policies } \\
\text { Country-level Regressions }{ }^{2}(n=68)\end{array}$} & \multicolumn{2}{|c|}{$\begin{array}{l}\text { Coefficient of Percentage of country test } \\
\text { score variance attributable to variance in } \\
\text { scores across schools on tracking policies } \\
(n=68)\end{array}$} \\
\hline & $\begin{array}{l}\text { Single Variate } \\
\text { Regression } \\
\end{array}$ & $\begin{array}{l}\text { Regression with } \\
\text { Covariates }^{3}\end{array}$ & $\begin{array}{l}\text { Single Variate } \\
\text { Regression }\end{array}$ & $\begin{array}{l}\text { Regression with } \\
\text { Covariates }^{3}\end{array}$ \\
\hline $\begin{array}{l}\text { School Tracking Policy } \\
\text { Dummy=1 for Tracking }\end{array}$ & $\begin{array}{l}4.12 * * * \\
(0.92) \\
\end{array}$ & $\begin{array}{l}2.59 * * * \\
(0.95) \\
\end{array}$ & $\begin{array}{l}14.40 * * * \\
(3.16)\end{array}$ & $\begin{array}{l}7.07 * * * \\
(2.58) \\
\end{array}$ \\
\hline $\begin{array}{l}\text { Tracking } \\
\text { Index based on age }\end{array}$ & $\begin{array}{l}1.11 * * * \\
(0.21) \\
\end{array}$ & $\begin{array}{l}0.83^{* * *} \\
(0.25) \\
\end{array}$ & $\begin{array}{l}3.74 * * * \\
(0.79) \\
\end{array}$ & $\begin{array}{l}2.54 * * * \\
(0.78) \\
\end{array}$ \\
\hline
\end{tabular}

\section{Panel B: School Level Regression}

\begin{tabular}{|c|c|c|}
\hline \multirow[b]{2}{*}{ Country Group } & \multicolumn{2}{|c|}{$\begin{array}{c}\text { Regression coefficient of school-fixed-effects on } \\
\text { school rank, with country dummies } \\
\text { (number of schools }=17,539 \text { ) }\end{array}$} \\
\hline & $\begin{array}{l}\text { Single Variate } \\
\text { regression }\end{array}$ & Regression with Covariates $^{5}$ \\
\hline $\begin{array}{l}\text { School Tracking Policy }= \\
0 \\
{[\text { n. schools }=6,288]}\end{array}$ & $\begin{array}{l}0.25 * * * \\
(0.003)\end{array}$ & $\begin{array}{l}0.20 * * * \\
(0.004)\end{array}$ \\
\hline $\begin{array}{l}\text { School Tracking Policy }= \\
1^{6} \\
{[\text { n. schools }=11,251]}\end{array}$ & $\begin{array}{l}0.36 * * * \\
(0.005)\end{array}$ & $\begin{array}{l}0.25 * * * \\
(0.005)\end{array}$ \\
\hline $\begin{array}{l}\text { Rank interacted with } \\
\text { Tracking } \\
\text { Index based on age * } \\
\text { Rank[all schools] }\end{array}$ & $\begin{array}{l}0.009 * * * \\
(0.002)\end{array}$ & $\begin{array}{l}0.002 \\
(0.001)\end{array}$ \\
\hline
\end{tabular}

Note: ${ }^{1}$ Analysis for 68 countries for which we have tracking information. Basic relations in the data similar to those with regression results for the entire sample. First age at which selection takes place in the education system. This information refers to the policy set at the national level. Several sources have been used to extract this information including Prof. Woessmann who kindly shared his dataset with us that was constructed through detailed countryspecific inquiries (OECD 2005, Education at a Glance, Table D6.1; OECD 2010d Table IV 3.2a; Hanushek and Woessmann 2006; Brunello and Checchi 2007, Schuetz et al. 2008; Woessmann 2005b; country-specific sources for Malta and India). Information on tracking was not available for the following countries: Costa Rica, Georgia, Kazakhstan, Mauritius, Miranda - Venezuela, Serbia.

${ }^{2}$ The analysis is carried out at the country-level and the dependent variable is the country-specific coefficient on school rank. These country-specific coefficients are available from the authors.

${ }^{3}$ These are country averages of: student's age, gender, grade, whether the language of test is the main language spoken at home, whether the student lives with two parents (natural or otherwise), immigrant status, parents' immigrant status, total school enrollment, dummies for community size where the school is located, index of socio-economic status (ESCS). Descriptive statistics related to these variables are presented in Tables A1 and 6. Student sampling weights are included.

${ }^{4}$ The dependent variable is school fixed effects. The coefficient presented in the table is related to the school ranking. Country dummies are included. School-level regressions are weighted by 1 /number of school.

${ }^{5}$ These are school averages of the control variables described in ${ }^{3}$.

${ }^{6}$ School tracking is equal to 1 if age at first selection is below 16 .

Significance level (based on clustering-robust standard errors): $*$ denotes significance at $10 \%$, ** denotes significance at $5 \%$, *** denotes significance at $1 \%$ 
Table 3: Regression Coefficients of Test Scores, School Fixed Effects and Coefficient of Variation of Scores Within Schools on Sorting Mechanisms, PISA $2009^{1}$

\begin{tabular}{|c|c|c|c|c|}
\hline VARIABLES ${ }^{2}$ & $\begin{array}{l}\text { Share of } \\
\text { Schools } \\
\text { with } \\
\text { Practice }\end{array}$ & School Test Score & $\begin{array}{l}\text { School Fixed } \\
\text { Effects }^{3} \\
\\
(2) \\
\end{array}$ & $\begin{array}{c}\text { Coefficient of } \\
\text { Variation } \\
\text { Of Scores Within } \\
\text { Schools } \\
(3) \\
\end{array}$ \\
\hline Tracking $^{4}$ & 63.79 & $\begin{array}{c}44.56 * * * \\
(2.133)\end{array}$ & $\begin{array}{c}43.53 * * * \\
(2.196)\end{array}$ & $\begin{array}{c}-1.26 * * * \\
(0.133)\end{array}$ \\
\hline Private school ${ }^{5}$ & 17.56 & $\begin{array}{c}-0.11 \\
(4.354)\end{array}$ & $\begin{array}{c}-1.23 \\
(4.002)\end{array}$ & $\begin{array}{c}-0.47 \\
(0.355)\end{array}$ \\
\hline Selective admissions & 30.17 & $\begin{array}{c}12.31 * * * \\
(2.344)\end{array}$ & $\begin{array}{c}12.78 * * * \\
(2.312)\end{array}$ & $\begin{array}{c}-0.81 * * * \\
(0.242)\end{array}$ \\
\hline Selective residence & 35.39 & $\begin{array}{l}-6.70 * * \\
(2.824)\end{array}$ & $\begin{array}{l}-7.81 * * \\
(3.082)\end{array}$ & $\begin{array}{c}0.19 \\
(0.238)\end{array}$ \\
\hline Constant & & $\begin{array}{l}684.84 * * * \\
(203.405)\end{array}$ & $\begin{array}{c}-56.31 \\
(220.866)\end{array}$ & $\begin{array}{l}43.64 * * \\
(18.878)\end{array}$ \\
\hline $\begin{array}{l}\text { Observations } \\
\text { R-squared }\end{array}$ & & $\begin{array}{c}17,252 \\
0.736 \\
\end{array}$ & $\begin{array}{c}17,252 \\
0.674 \\
\end{array}$ & $\begin{array}{c}17,252 \\
0.158 \\
\end{array}$ \\
\hline
\end{tabular}

${ }^{1}$ All regressions at school-level. Covariates in each regression include country dummies. The following controls are included: school-level average student age, gender, grade, whether the language of test is main language spoken at home, whether student lives with two parents), immigrant status, parents' immigrant status, index of socio-economic cultural status, school enrollment, dummies for community size where the school is located. School sampling weights are used. The analysis includes all the countries for which information on tracking is available. France excluded as the school questionnaire was not administered. 134 schools have no school-level variance as they have only one student.

${ }^{2}$ Full description of variables is provided in the appendix, section A2.

${ }^{3}$ School fixed effects have been extracted from the student-level regression of test scores on school dummies and child/parents control characteristics.

${ }^{4}$ The tracking index is used as explanatory variable. The share of practice refers to the share of schools where age at first selection is below 16 .

${ }^{5}$ Private schools refer to the management of schools. Results related to the governance of funding are available from the authors.

Robust standard errors clustered at the country-level in parentheses. Significance level: ${ }^{* * *} \mathrm{p}<0.01,{ }^{* *} \mathrm{p}<0.05, *$ $\mathrm{p}<0.1$ 
Table 4 Regression Coefficients of Test Scores and Coefficient of variation of scores within schools on School Policies and Practices, PISA $2009^{1}$

\begin{tabular}{|c|c|c|c|}
\hline & Test Score & $\begin{array}{l}\text { Coefficient } \\
\text { of variation }\end{array}$ & Test Score \\
\hline "Measures of School Policies or Practices" & $\begin{array}{c}\text { all countries } \\
{[n=67]}\end{array}$ & $\begin{array}{l}\text { of scores } \\
\text { within } \\
\text { schools }\end{array}$ & $\begin{array}{lc}\text { countries by tracking } \\
\text { no } & \text { yes } \\
{[\mathrm{n}=21]} & {[\mathrm{n}=46]}\end{array}$ \\
\hline
\end{tabular}

(1)

(2)

(3)

(4)

\section{POLICIES}

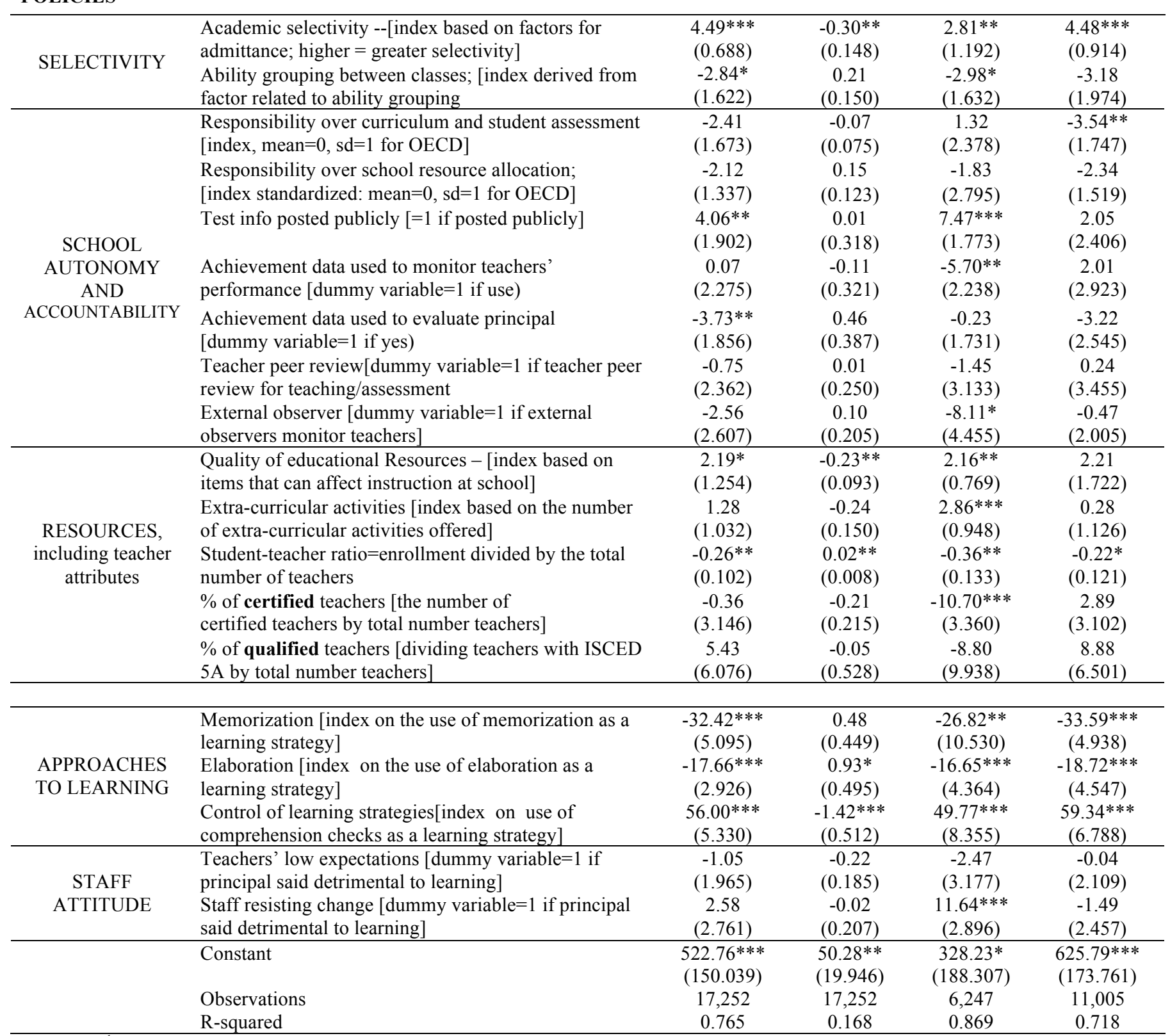

Note: ${ }^{1}$ All regressions at school-level. Covariates in each regression include country dummies. The following controls are included: school-level average student age, gender, grade, whether the language of test is main language spoken at home, whether student lives with two parents), immigrant status, parents' immigrant status, index of socio-economic cultural status, school enrollment, dummies for community size where the school is located. School sampling weights are used. The empirical analysis includes all the countries for which information on tracking is available. France excluded as the school questionnaire was not administered. 134 schools have no school-level variance as they have only one student. ${ }^{2}$ Full description of variables is presented in the appendix, section A2. Descriptive statistics are in Table A3.

Robust standard errors clustered at the country-level in parentheses. Significance level: *** $\mathrm{p}<0.01,{ }^{* *} \mathrm{p}<0.05,{ }^{*} \mathrm{p}<0.1$ 
Table 5: School Fixed Effects and Residual Variances for Different Specifications ${ }^{1}$

\begin{tabular}{llcc}
\hline & VARIABLES & $\begin{array}{c}\text { Residual variance in } \\
\text { estimated } \\
\text { school fixed effect } \\
(1)\end{array}$ & $\mathrm{R}^{2}$ \\
\hline & School fixed effects $^{2}$ & 5684.050 & $(2)$ \\
\hline$[1]$ & Policies and practices $^{3}$ & 3166.016 & 0.443 \\
{$[2]$} & Country dummies $^{4}$ & 2694.240 & 0.526 \\
{$[3]$} & $\begin{array}{l}\text { Policies and practices } \\
\text { with country } \\
\text { dummies }\end{array}$ & 2051.942 & 0.639 \\
\hline
\end{tabular}

\begin{tabular}{|c|c|c|c|}
\hline [4] & $\begin{array}{l}\text { School-level } \\
\text { covariates }^{6}\end{array}$ & 4467.663 & 0.214 \\
\hline [5] & $\begin{array}{l}\text { School-level } \\
\text { covariates with } \\
\text { policies and practices }{ }^{7}\end{array}$ & 2370.249 & 0.583 \\
\hline [6] & $\begin{array}{l}\text { School-level } \\
\text { covariates with } \\
\text { country dummies }^{8}\end{array}$ & 2392.985 & 0.579 \\
\hline [7] & $\begin{array}{l}\text { School-level } \\
\text { covariates with } \\
\text { policies and practices } \\
\text { and country dummies } 9\end{array}$ & 1659.743 & 0.708 \\
\hline
\end{tabular}

\footnotetext{
Note: ${ }^{1}$ Results presented in the table are derived from school-level regressions (total number of schools $=17,252$ ). The dependent variable is school fixed effects. France excluded as the school questionnaire was not administered. School sampling weights are used. Analysis based on clustering-robust standard errors.

${ }^{2}$ School fixed effects have been extracted from a student-level regression which includes student background characteristics and school dummies.

${ }^{3}$ The regression includes as explanatory variables school policies and practices. These are the policies and practices presented in Table 4 and described in the Appendix, section A2.

${ }_{5}^{4}$ The regression includes as explanatory variables country dummies.

${ }^{5}$ The regression includes as explanatory variables school policies and practices as described above, and country dummies.

${ }^{6}$ The regression includes as explanatory variables school-level covariates. Covariates include the following variables: school-level average student age, gender, grade, whether the language of test is main language spoken at home, whether student lives with two parents), immigrant status, parents' immigrant status, index of socio-economic cultural status, school enrollment, dummies for community size where the school is located.

${ }^{7}$ The regression includes as explanatory variables school-level covariates as described above, and school policies and practices.

${ }^{8}$ The regression includes as explanatory variables school-level covariates as described above and country dummies.

${ }^{9}$ The regression includes as explanatory variables school-level covariates as described above, school policies and practices, and country dummies.
} 
Table 6: Mean of Family Background Measures, PISA 2009

\begin{tabular}{|l|c|c|c|}
\hline Country Group $^{\mathbf{7}}$ & $\begin{array}{c}\text { Years of } \\
\text { Schooling }^{\mathbf{1}}\end{array}$ & Books at Home $^{\mathbf{3}}$ & $\begin{array}{c}\text { Index of Economic, Social } \\
\text { and Cultural Status (ESCS) }\end{array}$ \\
\hline & Mean $^{2}$ & Mean Category & Mean $^{\mathbf{6}}$ \\
\hline All & 12.17 & 2.82 & -0.54 \\
OECD & $(3.63)$ & $(1.42)$ & $(1.21)$ \\
\hline EU 15+ ${ }^{\mathbf{8}}$ & 13.11 & 3.16 & -0.03 \\
& $(3.11)$ & $(1.45)$ & $(1.01)$ \\
\hline Asian & 13.45 & 3.32 & 0.02 \\
& $(2.98)$ & $(1.44)$ & -0.15 \\
\hline Other High & 13.56 & 3.45 & $(0.82)$ \\
Income & $(2.39)$ & $(1.37)$ & -0.20 \\
\hline Middle Income & 13.28 & 3.30 & $(0.82)$ \\
& $(1.77)$ & $(1.36)$ & -1.18 \\
& 10.77 & 2.26 & $(1.22)$ \\
\hline
\end{tabular}

Note: Sampling probability weights have been used in order to provide descriptive statistics representative for each country

${ }^{1}$ Highest level of education of either parent according to the ISCED classification. Parental education has been converted into years of schooling according to a country-specific scale provided in PISA 2009 (Vol. I, Table A1.1, p.168) [completed primary education (ISCED 1); completed secondary education (ISCED 2 (lower secondary), ISCED Level 3B or 3C (vocational/pre-vocational upper secondary); ISCED 3A (upper secondary) and/or ISCED 4 (non-tertiary post-secondary)); completed tertiary education, that is theoretically oriented tertiary and post-graduate (ISCED 5A, 6)].

${ }_{3}^{2}$ Average years of schooling with standard deviation in parentheses.

${ }^{3}$ Books at home shows the share of individuals according to the number of books they report having in their home.

${ }^{4}$ Mean of the books-at-home categories (1-6). These are the six categories: $1=1-10$ books, $2=11-25$ books, $3=26-100,4=101-200,5=201-500,6=$ more than 500 books. Standard deviation in parentheses.

${ }^{5}$ The ESCS index is constructed by using the following three sub-components: the higher parental occupation index, the higher parental education index and the index of home possessions.

${ }^{6}$ Mean of the ECSC index. Standard deviation in parentheses.

${ }^{7}$ Only a low-income country participated to the PISA 2009 study: Kyrgyzstan, so we did not include this group. The analysis has been carried out for this country and is available from the authors upon request.

8 This category includes Austria, Belgium, Denmark, Finland, France, Germany, Greece, Ireland, Italy, Luxembourg, the Netherlands, Portugal, Spain, Sweden and the United Kingdom, Norway and Switzerland. 
Table 7: Regression coefficients of Student Test Scores on ESCS Measure of Family Background PISA 2009

\begin{tabular}{|c|c|c|c|c|c|c|c|}
\hline & $\begin{array}{l}\text { Country Group } \\
\text { [number of } \\
\left.\text { observations }{ }^{2,3}\right]\end{array}$ & All & & $\begin{array}{l}\text { Without School } \\
\text { Tracking }^{4}\end{array}$ & & $\begin{array}{l}\text { With School } \\
\text { Tracking }\end{array}$ & \\
\hline & & ESCS coefficient & $\mathrm{R}^{2}$ & ESCS coefficient & $\mathrm{R}^{2}$ & ESCS coefficient & $\mathrm{R}^{2}$ \\
\hline [1] & $\begin{array}{l}\text { Test Score on } \\
\text { ESCS } \\
\text { (with } \\
\text { country fixed } \\
\text { effects) }\end{array}$ & $\begin{array}{c}31.21 * * * \\
(0.536)\end{array}$ & 0.42 & $\begin{array}{c}31.48^{* * *} \\
(1.030)\end{array}$ & 0.41 & $\begin{array}{c}31.09 * * * \\
(0.609)\end{array}$ & 0.42 \\
\hline [2] & $\begin{array}{l}\text { Test Score on } \\
\text { ESCS } \\
\text { with other } \\
\text { covariates } \\
{ }^{6}, \\
\text { country fixed } \\
\text { effects) }\end{array}$ & $\begin{array}{c}24.20 * * * \\
(0.497)\end{array}$ & 0.48 & $\begin{array}{c}25.62 * * * \\
(0.899)\end{array}$ & 0.48 & $\begin{array}{c}23.05 * * * \\
(0.572)\end{array}$ & 0.49 \\
\hline [3] & $\begin{array}{l}\text { Test Score on } \\
\text { ESCS }{ }^{5} \text { with school } \\
\text { fixed effects and } \\
\text { other covariates }\end{array}$ & $\begin{array}{c}10.28 * * * \\
(0.317)\end{array}$ & 0.66 & $\begin{array}{c}13.02 * * * \\
(0.644)\end{array}$ & 0.62 & $\begin{array}{l}8.53 * * * \\
(0.309)\end{array}$ & 0.69 \\
\hline [4] & $\begin{array}{l}\text { Test Score on } \\
\text { ESCS }^{5} \text { with } \\
\text { Parental } \\
\text { Involvement } \\
\text { indicators }{ }^{7} \\
\text { other covariates } \\
\text { school fixed effects) } \\
\text { schol }\end{array}$ & $\begin{array}{c}9.39 * * * \\
(0.51)\end{array}$ & 0.64 & $\begin{array}{c}15.80 * * * \\
(1.07)\end{array}$ & 0.44 & $\begin{array}{c}8.88 * * * \\
(0.55)\end{array}$ & 0.65 \\
\hline
\end{tabular}

Note: Regressions weighted by the students' sampling probabilities.

${ }^{1}$ Estimates using parents' education and number of books at home available from the authors upon request.

${ }^{2}$ Number of observations in [4] for the 14 countries that administered the parental involvement questionnaire. Regressions [1]-[3] estimated for the 14 country sample given similar results to those in the table. Results are available from the authors. Detailed descriptive statistics related to the parental involvement variables are available from the authors.

${ }^{3}$ The number of observations for the different groups of countries and related estimation is the following: All: ([1]-[3]: 515,956; [4]:101,370); Without school tracking ([1]-[3]: 171,885; [4]: 21,356); With school tracking ([1]-[3]: 316,357; [4]: 80,014).

${ }^{4}$ The "without school tracking" group includes countries where age at first selection of students into different tracks is equal to 16 or higher. The group "with school tracking" includes countries where age at first selection is below 16. Information on school tracking: sources used to derive this variable are described in the footnote of Table 2. The country-specific information on school tracking is available from the authors.

${ }^{5}$ The ESCS index is constructed from the following three sub-components: the higher parental occupation index, the higher parental education index and the index of home possessions.

${ }^{6}$ Covariates: student age, gender, grade, whether the language of test is the main language spoken at home, whether the student lives with two parents, immigrant status, parents' immigrant status, school enrollment, dummies for community size where the school is located.

${ }^{7}$ Parental involvement is measured with four indices extracted from the parental questionnaire described in the appendix: "parental involvement", "resources", "early support at ISCED1", "current support".

Significance level (based on clustering-robust standard errors): $*$ denotes significance at $10 \%,{ }^{* *}$ denotes significance at $5 \%$, $* *$ denotes significance at $1 \%$ 
SCHOOL AND FAMILY EFFECTS

\section{APPENDIX}

Table A1: Descriptive Statistics of the Control Variables, PISA 2009

\begin{tabular}{|c|c|c|c|c|c|c|c|c|c|c|c|c|}
\hline & Students & & & & & & & & Schools & & & \\
\hline Country Group & $\begin{array}{c}\text { Female } \\
(\%)\end{array}$ & Age & Grade $^{1}$ & $\begin{array}{l}\text { Immigrant } \\
\text { Background (\%) }\end{array}$ & $\begin{array}{l}\text { Mother Immigrant } \\
\text { Background (\%) }\end{array}$ & $\begin{array}{l}\text { Father } \\
\text { Immigrant } \\
\text { Background (\%) }\end{array}$ & $\begin{array}{l}\text { Language of } \\
\text { Test Spoken } \\
\text { at Home }(\%)^{3}\end{array}$ & $\begin{array}{l}\text { Live with } \\
\text { Two } \\
\text { Parents } \\
(\%)^{4} \\
\end{array}$ & $\begin{array}{l}\text { School } \\
\text { Size }^{5}\end{array}$ & $\begin{array}{l}\text { Village } \\
(\%)^{6}\end{array}$ & $\begin{array}{l}\text { Town } \\
(\%)^{7}\end{array}$ & $\begin{array}{l}\text { City } \\
(\%)^{\varepsilon}\end{array}$ \\
\hline All & 50.39 & $\begin{array}{l}15.78 \\
(0.29) \\
\end{array}$ & $\begin{array}{l}-0.06 \\
(0.72)\end{array}$ & 3.80 & 9.50 & 9.58 & 85.02 & 75.46 & $\begin{array}{l}967.82 \\
(812.80) \\
\end{array}$ & 12.69 & 46.80 & 40.51 \\
\hline OECD & 49.34 & $\begin{array}{l}15.79 \\
(0.29) \\
\end{array}$ & $\begin{array}{l}-0.07 \\
(0.60)\end{array}$ & 6.41 & 17.09 & 17.32 & 90.18 & 78.45 & $\begin{array}{l}995.21 \\
(719.58) \\
\end{array}$ & 9.19 & 53.60 & 37.2 \\
\hline EU15+ & 49.90 & $\begin{array}{l}15.79 \\
(0.29)\end{array}$ & $\begin{array}{l}-0.16 \\
(0.62)\end{array}$ & 6.85 & 16.20 & 16.45 & 90.04 & 81.88 & $\begin{array}{l}761.55 \\
(464.77)\end{array}$ & 5.63 & 66.53 & 27.8 \\
\hline Asian & 48.29 & $\begin{array}{l}15.75 \\
(0.29) \\
\end{array}$ & $\begin{array}{l}-0.10 \\
(0.34) \\
\end{array}$ & 1.54 & 3.35 & 2.61 & 95.49 & 84.40 & $\begin{array}{l}1159.59 \\
(922.74) \\
\end{array}$ & 0.26 & 23.77 & $75.9^{\prime}$ \\
\hline Other High Income & 50.29 & $\begin{array}{l}15.80 \\
(0.29) \\
\end{array}$ & $\begin{array}{l}0.15 \\
(0.65)\end{array}$ & 7.29 & 17.53 & 17.97 & 90.17 & 71.78 & $\begin{array}{l}559.60 \\
(490.22) \\
\end{array}$ & 19.47 & 35.60 & 44.9 . \\
\hline Middle Income & 51.90 & $\begin{array}{l}15.77 \\
(0.29)\end{array}$ & $\begin{array}{l}-0.07 \\
(0.87)\end{array}$ & 1.22 & 2.26 & 2.36 & 76.92 & 70.77 & $\begin{array}{l}959.62 \\
(880.66)\end{array}$ & 17.41 & 47.60 & 35.01 \\
\hline
\end{tabular}

Note: mean value weighted by sampling probabilities; standard deviation (only for discrete variables)

${ }^{1}$ Grade is compared to modal grade in country (classified as 0 )

${ }^{2}$ Students foreign-born, that is born in a country different from country of test

${ }^{3}$ Language of test spoken at home most of the time

${ }^{4}$ Live with two (natural or otherwise) parents

${ }^{5}$ Total school enrolment

${ }^{6}$ Community size where the school is located: a village, hamlet or rural area (fewer than 3,000 people)

Community size where the school is located: either a small town (from 3,000 to about 15,000 people) or a town (from 15,000 to about 100,000 people)

${ }^{8}$ Community size where the school is located: either a city (from 100,000 to 1 million people) or a large city (with over 1 million people) 


\section{$\underline{\text { Section A2: Variables }}$}

The list below describes the variables used in this study that have been extracted from the PISA database (http://pisa2009.acer.edu.au). A thorough description is provided in the School, Student Questionnaires, the related Codebooks and PISA 2009 Technical Report (OECD 2010d, 2012a). The variable related to tracking has been extracted from various sources and is available from the authors.

\section{TRACKING}

School Tracking Policy is a dummy variable $=1$ if age at first selection is below 16

Tracking Index is based on the actual age at first selection. The index varies between 10 and 18. Ages have been reverse coded.

\section{OTHER SORTING MECHANISMS}

Private School is a dummy variable $=1$ if the school is private

Private Funding is the share of funding provided by private sources

Selective Admissions is a dummy variable $=1$ if student's record of academic performance (including placement tests) is always considered when students are admitted to the school

Selective Residence is a dummy variable $=1$ if residence in a particular area is always considered when students are admitted to the school

\section{POLICIES}

\section{$\underline{\text { School Autonomy }}$}

The Index of the Relative Level of Responsibility of School Staff Relating to Curriculum and Assessment was computed from four items measuring the school principal's report concerning who had responsibility for curriculum and assessment. The index was standardized to having an OECD mean of zero and a standard deviation of one

The Index of the Relative Level of Responsibility of School Staff in Allocating Resources was derived from six items measuring the school principals' report on who has considerable responsibility for tasks regarding school management of resource allocation. The index was standardized to having an OECD mean of zero and a standard deviation of one

\section{$\underline{\text { Resources }}$}

The Index on the School's Educational Resources was computed on the basis of seven items measuring the school principal's perceptions of potential factors hindering instruction at school. All items were inverted for IRT scaling and positive WLE scores indicate better quality of educational resources

The Index of Extra-Curricular Activities Offered by School is based school principals reports what extra-curricular activities occur at their school. Responses to the items were coded such that positive WLE scores indicate higher levels of extracurricular school activities

The Student-Teacher Ratio is enrollment by the total number of teachers

Teacher Characteristics

The Proportion of Fully Certified Teachers was computed by dividing the number of fully certified teachers by the total number of teachers

The Proportion of Teachers with a University Education is the number of teachers with ISCED 5A qualification divided by the total number of teachers

\section{Selectivity}

The Index of Ability Grouping between Classes was derived from the two items by assigning schools to three categories: (1) schools with no ability grouping for any subjects, (2) schools with one of these forms of ability grouping between classes for some subjects and (3) schools with one of these forms of ability grouping for all subjects

The Index of Academic School Selectivity was computed by assigning schools to three different categories: (1) schools where neither of these two factors is considered for student admittance, (2) schools considering at least one of these two factors, (3) schools where at least one of these two factors is a prerequisite for student admittance

\section{$\underline{\text { Accountability }}$}

Achievement data are posted publicly is a dummy variable $=1$ if school principals said achievement data was posted publicly during the past year

Achievement data are used in evaluation of the principal's performance is a dummy variable $=1$ if school principals said achievement data was used to monitor the principal's performance during the past year

Achievement data are used in evaluation of teachers' performance is a dummy variable $=1$ if school principals said achievement data was used to monitor teachers' performance during the past year 
Teacher peer-review is a dummy variable $=1$ if school principals said teacher peer review was used to monitor teachers during the past year

External observers is a dummy variable $=1$ if school principals said external observers were used to monitor teachers during the past year

\section{PRACTICES}

\section{$\underline{\text { Approaches to Learning }}$}

Index of Memorization. Positive WLE scores on these indices indicate higher importance attached to the given reading strategy. Four items measuring the construct of memorization were included in the PISA 2009 main study

Index of Elaboration. Positive WLE scores on these indices indicate higher importance attached to the given reading strategy. Four items measuring the construct of elaboration were included in the PISA 2009 main study

Index of Control Learning Strategies. Positive WLE scores on these indices indicate higher importance attached to the given reading strategy. Five items measuring the construct of control learning strategies were included in the PISA 2009 main study

\section{$\underline{\text { Staff Attitude }}$}

Teachers' Low Expectations as detrimental to the learning of students is a dummy variable $=1$ if school principals said it was to some extent or a lot extent or a lot

Staff Resisting Change as detrimental to the learning of students is a dummy variable $=1$ if school principals said to some

\section{FAMILY BACKGROUND}

Years of Schooling is the highest level of education of either parent according to the ISCED classification

Books at Home provides the share of individuals according to the number of books they report having in their home

The Index of Economic, Social and Cultural Status is constructed by using three sub-components: the higher parental occupation index, the higher parental education index and the index of home possessions

\section{PARENTAL INVOLVEMENT}

The Index of the Early Activities with the Child when the Child attended the First Year of ISCED 1 is related to parental support of child's reading literacy and based on the information provided by parents. Positive WLE scores indicate greater parental support of child's reading literacy at the beginning of ISCED 1

The Index of the Current Activities with the Child is related to parental support in home activities and is based on the information provided by parents. Positive WLE scores indicate greater parental support of child's reading literacy

The Index of Parental Involvement is related to parents' participation in school-related activities and is based on the information provided by parents. Positive WLE scores indicate greater parental involvement in their child's school

The Index of Resources Available to the Child is related to resources available to the child at home and is based on the information provided by parents. Positive WLE scores indicate greater availability of reading resources at home 
Table A3: School Policies and Practices, PISA 2009

\section{A] POLICIES}

\begin{tabular}{|c|c|c|c|c|c|c|c|}
\hline \multirow[t]{2}{*}{ Country } & \multicolumn{2}{|c|}{ School Autonomy } & \multicolumn{3}{|l|}{ Resources } & \multicolumn{2}{|l|}{ Selectivity } \\
\hline & $\begin{array}{l}\text { Responsibility } \\
\text { over } \\
\text { curriculum and } \\
\text { assessment }\end{array}$ & $\begin{array}{l}\text { Responsibility } \\
\text { over resource } \\
\text { allocation }^{1}\end{array}$ & $\begin{array}{l}\text { Teacher- } \\
\text { student } \\
\text { ratio }^{1}\end{array}$ & $\begin{array}{l}\text { Quality of } \\
\text { educational } \\
\text { resources }\end{array}$ & $\begin{array}{l}\text { Extra-curricular } \\
\text { activities }\end{array}$ & $\begin{array}{l}\text { Academic } \\
\text { Selectivity } \\
\text { (\%) }\end{array}$ & $\begin{array}{l}\text { Ability Grouping } \\
\text { between Classes }^{3} \\
(\%)\end{array}$ \\
\hline All & $\begin{array}{l}-0.18 \\
(0.98)\end{array}$ & $\begin{array}{l}-0.12 \\
(0.93)\end{array}$ & $\begin{array}{l}17.77 \\
(11.92)\end{array}$ & $\begin{array}{l}-0.28 \\
(1.20)\end{array}$ & $\begin{array}{l}0.36 \\
(1.03)\end{array}$ & 41.45 & 18.97 \\
\hline OECD & $\begin{array}{l}-0.14 \\
(0.96)\end{array}$ & $\begin{array}{l}0.05 \\
(0.98)\end{array}$ & $\begin{array}{l}14.82 \\
(5.98)\end{array}$ & $\begin{array}{l}0.14 \\
(1.08)\end{array}$ & $\begin{array}{l}0.54 \\
(0.92)\end{array}$ & 33.46 & 11.36 \\
\hline EU15+ & $\begin{array}{l}0.04 \\
(0.96)\end{array}$ & $\begin{array}{l}-0.10 \\
(1.00)\end{array}$ & $\begin{array}{l}12.81 \\
(4.79)\end{array}$ & $\begin{array}{l}0.10 \\
(0.93)\end{array}$ & $\begin{array}{l}0.21 \\
(0.89)\end{array}$ & 36.43 & 12.16 \\
\hline Asian & $\begin{array}{l}0.81 \\
(0.83)\end{array}$ & $\begin{array}{l}-0.17 \\
(0.98)\end{array}$ & $\begin{array}{l}14.62 \\
(5.22)\end{array}$ & $\begin{array}{l}0.36 \\
(1.02)\end{array}$ & $\begin{array}{l}0.52 \\
(0.92)\end{array}$ & 71.82 & 8.42 \\
\hline $\begin{array}{l}\text { Other High } \\
\text { Income }\end{array}$ & $\begin{array}{l}-0.37 \\
(0.80)\end{array}$ & $\begin{array}{l}-0.09 \\
(0.70)\end{array}$ & $\begin{array}{l}11.86 \\
(4.51)\end{array}$ & $\begin{array}{l}-0.57 \\
(0.96)\end{array}$ & $\begin{array}{l}0.70 \\
(0.88)\end{array}$ & 26.52 & 36.23 \\
\hline Middle Income & $\begin{array}{l}-0.41 \\
(0.92)\end{array}$ & $\begin{array}{l}-0.27 \\
(0.88)\end{array}$ & $\begin{array}{l}22.24 \\
(15.94)\end{array}$ & $\begin{array}{l}-0.76 \\
(1.17) \\
\end{array}$ & $\begin{array}{l}0.10 \\
(1.12)\end{array}$ & 43.83 & 25.97 \\
\hline
\end{tabular}

\begin{tabular}{|c|c|c|c|c|c|c|c|}
\hline \multirow[t]{2}{*}{ Country } & \multicolumn{2}{|l|}{ Teachers } & \multicolumn{5}{|l|}{ Accountability } \\
\hline & $\begin{array}{l}\text { Share of } \\
\text { qualified } \\
\text { teachers }\end{array}$ & $\begin{array}{l}\text { Share of } \\
\text { certified } \\
\text { teachers }\end{array}$ & $\begin{array}{l}\text { Achievement } \\
\text { data posted } \\
\text { publicly }(\% \\
\text { yes) }\end{array}$ & $\begin{array}{l}\text { Achievement data } \\
\text { used to evaluate } \\
\text { principal (\% yes) }\end{array}$ & $\begin{array}{l}\text { Achievement data } \\
\text { used to evaluate } \\
\text { teachers } \\
\text { (\% yes) }\end{array}$ & $\begin{array}{l}\text { Teacher peer- } \\
\text { review } \\
\text { (\% yes) }\end{array}$ & $\begin{array}{l}\text { External observers } \\
\text { (\% yes) }\end{array}$ \\
\hline All & 82.26 & 75.48 & 42.59 & 50.33 & 60.49 & 66.32 & 44.97 \\
\hline OECD & 83.67 & 82.81 & 53.03 & 44.29 & 42.92 & 50.00 & 34.47 \\
\hline EU15+ & 69.22 & 87.68 & 26.44 & 26.65 & 33.06 & 42.11 & 24.38 \\
\hline Asian & 96.05 & 96.75 & 16.38 & 18.07 & 34.45 & 60.21 & 36.41 \\
\hline $\begin{array}{l}\text { Other High } \\
\text { Income }\end{array}$ & 86.90 & 94.79 & 70.42 & 76.79 & 93.84 & 93.19 & 68.86 \\
\hline Middle Income & 77.07 & 60.63 & 33.99 & 59.47 & 78.59 & 79.68 & 53.40 \\
\hline
\end{tabular}

Note: Sampling probability weights have been used in order to provide descriptive statistics representative for each country. Policy and Practice

variables are described in the appendix, section A2.

${ }^{1}$ Mean of the index and standard deviation (in parentheses) ${ }^{2}$ At least one factor is considered for school admittance (see variable description) ${ }^{3}$ for all subjects. 
Table A3 (cont'd): School Policies and Practices, PISA 2009

\section{B] PRACTICES}

\begin{tabular}{|c|c|c|c|c|c|}
\hline \multirow[t]{2}{*}{ Country } & \multicolumn{3}{|c|}{ Approaches to Learning } & \multicolumn{2}{|l|}{ Staff Attitude } \\
\hline & $\begin{array}{l}\text { Memoriz } \\
\text { ation }^{1}\end{array}$ & Elaboration $^{1}$ & $\begin{array}{l}\text { Control of } \\
\text { learning } \\
\text { strategies }{ }^{1}\end{array}$ & $\begin{array}{l}\text { Teachers' low } \\
\text { expectations } \\
\text { (\% yes) }\end{array}$ & $\begin{array}{l}\text { Staff resisting } \\
\text { change }^{2} \\
\text { (\% yes) }\end{array}$ \\
\hline All & $\begin{array}{l}0.09 \\
(0.97)\end{array}$ & $\begin{array}{l}0.10 \\
(0.98)\end{array}$ & $\begin{array}{l}-0.04 \\
(0.97)\end{array}$ & 27.98 & 29.14 \\
\hline OECD & $\begin{array}{l}0.02 \\
(1.00)\end{array}$ & $\begin{array}{l}-0.01 \\
(1.02)\end{array}$ & $\begin{array}{l}0.05 \\
(1.02)\end{array}$ & 23.76 & 31.01 \\
\hline EU15+ & $\begin{array}{l}0.02 \\
(0.94)\end{array}$ & $\begin{array}{l}-0.04 \\
(0.96)\end{array}$ & $\begin{array}{l}0.07 \\
(0.96)\end{array}$ & 17.06 & 24.41 \\
\hline Asian & $\begin{array}{l}-0.34 \\
(1.05)\end{array}$ & $\begin{array}{l}-0.31 \\
(1.09)\end{array}$ & $\begin{array}{l}-0.41 \\
(1.02)\end{array}$ & 31.17 & 36.18 \\
\hline $\begin{array}{l}\text { Other High } \\
\text { Income }\end{array}$ & $\begin{array}{l}0.22 \\
(0.85)\end{array}$ & $\begin{array}{l}0.09 \\
(0.93)\end{array}$ & $\begin{array}{l}-0.11 \\
(0.86)\end{array}$ & 37.68 & 33.24 \\
\hline $\begin{array}{l}\text { Middle } \\
\text { Income }\end{array}$ & $\begin{array}{l}0.24 \\
(0.89)\end{array}$ & $\begin{array}{l}0.30 \\
(0.88)\end{array}$ & $\begin{array}{l}-0.03 \\
(0.90)\end{array}$ & 29.88 & 25.06 \\
\hline
\end{tabular}

Note: Sampling probability weights have been used in order to provide descriptive statistics representative

for each country. Policy and Practice variables are described in the appendix, section A2.

${ }^{1}$ Mean of the index and standard deviation (in parentheses).

${ }^{2}$ Perceived by the school principal as detrimental to the learning of students. 